\title{
Satellite and in situ observations of a late winter phytoplankton bloom, in the northern Bay of Biscay
}

\author{
Francis Gohin $^{\star, a}$, Luis Lampert ${ }^{\mathrm{b}, 1}$, Jean-François Guillaud ${ }^{\mathrm{a}}$, Alain Herbland ${ }^{\mathrm{c}}$ and Elisabeth Nézan ${ }^{\mathrm{d}}$ \\ a IFREMER Centre de Brest, BP 7029280 Plouzane, Brittany 29280, France \\ ${ }^{\mathrm{b}}$ EPSHOM/CMO/CM, BP 42629275 Brest, Cédex, Brittany, France \\ c CREMA L'Houmeau, BP 5 17137, L'Houmeau, France \\ d IFREMER, 13 rue de Kérose, 29187 Concarneau, Cedex, Brittany, France \\ *: Corresponding author : Francis.Gohin@ifremer.fr, FAX: (33) 298224533
}

\begin{abstract}
:
A phytoplankton bloom was observed in late winter 2000 , on the continental shelf offshore of southern Brittany, in northwestern Bay of Biscay. This bloom appeared initially along the 120-m isobath, in stratified and clear waters, at the interface between the oceanic water and the plumes of southern Brittany rivers (mainly the Loire and Vilaine). The development of the bloom was triggered by favourable meteorological conditions, characterised by solar irradiance reaching the maximum level expected for that period of the year.

Outside of the bloom area, the phytoplankton photosynthesis was irradiance limited: inshore, because of the stronger attenuation of the light; offshore, because of the weak stratification. The hydrological conditions at the onset of the bloom were observed in the field, during the oceanographic cruise MODYCOT. However, without SeaWiFS, the only observations related to this major event in the primary production would have been those of the coastal phytoplankton network (REPHY (REseau PHYtoplankton)).

Observed initially offshore by SeaWiFS, as early as March 5, 2001, the phytoplankton bloom extended onshore and was observed at REPHY stations by mid-March. On, March 15, fishermen reported that they were handicapped in trawling, the presence of mucilage in their nets carried clogging by very heavy slime. This mucilage has been shown to be produced by the diatom Coscinodiscus and, especially, C. wailesii. These observations were made as the main bloom was declining.

A simple calculation, based upon the SeaWiFS chlorophyll concentration maps observed from March 5-16, shows that phosphate was probably totally depleted offshore, by March 16 . The former bloom area appeared very poor in chlorophyll on the SeaWiFS image of April 7, which was the first image available after 3 weeks of an overcast sky. A second cruise undertaken at the end of April confirmed the phosphate depletion and the low chlorophyll concentration in that area.
\end{abstract}

Keywords: Satellite sensing; Ocean colour; Phytoplankton; Algal bloom; Coscinodiscus; Bay of Biscay 


\section{Introduction}

The Bay of Biscay belongs to the Northeast Atlantic Shelves Province, one of the 56 marine provinces defined by Longhurst (1998). According to chlorophyll data from the Coastal Zone Colour Scanner (CZCS), Longhurst (1998) recognized four ecological seasons in that province: (i) mixed conditions and light limitation in winter, (ii) a nutrient limited spring bloom, (iii) stratified conditions during summer with a deep chlorophyll maximum, and (iv) a second general bloom when the autumn gales break down the summer stratification. However, in the Southeastern Bay of Biscay, significant winter blooms within the Gironde plume were pointed out by Labry et al. (2001). The early outburst of these blooms was due to an increase of light availability in anticyclonic weather conditions; the phytoplankton can then develop within a thin surface layer related to haline stratification during high river flow. In the northwestern part of the Bay of Biscay, Morin et al. (1991) showed that halostratification was responsible for phytoplankton blooms in frontal zones of South and West Brittany. Chlorophyll $a$ concentrations reported by these authors are $2 \mathrm{mg} \mathrm{m}^{-3}$ or less in March, off South Brittany.

Thus, at the end of winter, it is known that blooms can occur over the continental shelf of the Bay of Biscay when the solar irradiance reaches the highest values available for that season. Such conditions are generally observed when the sky is cloud free. These meteorological situations are particularly suitable for the application of the ocean color techniques to the data of the Sea-viewing Wide Field-of-view Sensor (SeaWiFS). SeaWiFS is the NASA follow-on sensor to CZCS, which ceased operations in June 1986. Since its launch in September 1997, SeaWiFS has been providing very useful data for monitoring the phytoplankton biomass of clear waters. Using SeaWiFS water leaving radiance at different channels, many algorithms (O'Reilly et al., 1998) are proposed to provide estimates of the 
chlorophyll concentration at the surface for case 1 water, i.e. water where the optical properties are dominated by the phytoplankton and its degradation products. For the coastal waters, where the optical properties derive mainly from scattering and absorption by suspended matters or colored dissolved organic material (CDOM) of terrestrial origin, the chlorophyll concentration can only be approached. Calibrated on in situ data measured in the English Channel and in the Bay of Biscay, an empirical case 2 water algorithm has been proposed by Gohin et al. (2002). From an optical point of view, the bloom which is described in this study occurred in clear waters, classified as case 1, corresponding to the $120-80 \mathrm{~m}$ isobaths. For this type of water, the chlorophyll concentrations derived from SeaWiFS data are particularly reliable.

To explain the onset of the March 2000 bloom, we will analyze the environmental conditions (nutrients, light attenuation, stratification) through observations collected during the MODYCOT cruise which preceded the bloom. The irradiance during the development of the bloom will be estimated from the solar flux at the ocean surface derived from the geostationnary satellite METEOSAT. In addition, the potential utility of remote sensing for fisheries will be discussed as one species within this phytoplankton bloom (Coscinodiscus) caused a serious handicap to trawling by producing extracellular mucilage. The first occurrence of C. wailesii in the north-east Atlantic Ocean has been reported by Boalch and Harbour (1977). According to Rincé et Paulmier (1986) this diatom appeared in the Bay of Biscay between 1972 and 1981. 


\section{Methods}

\subsection{In situ observations during the MODYCOT cruise}

In situ measurements of the main physical and chemical parameters prevailing before the bloom were carried out during the MODYCOT 2000 cruise (Service Hydrographique et Océanographique de la Marine (SHOM) and IFREMER joint project) aboard the R.V. BH2 Laperouse (Fig. 1). A network of 41 stations was sampled between March 1 and March 6 . Vertical profiles of temperature, conductivity and depth (CTD Sea Bird 911+) were recorded at every station. Seawater was sampled, with $5 \mathrm{~L}$ Niskin bottles, for pigments and nutrients (nitrite + nitrate, phosphate and silicate). The Loire-Vilaine section, transect $\mathrm{N}^{\circ} 4$ on Fig. 1, was sampled in detail, and vertical profiles of nutrients are provided. For every transect, vertical profiles of temperature, salinity and transmissiometry were carried out. A transmissiometer (Wet-Labs) was connected to the CTD and profiles of transmittance at $660 \mathrm{~nm}$ through a $10 \mathrm{~cm}$ path were achieved. Profiles of Photosynthetic Available Radiation (PAR, 400$700 \mathrm{~nm}$ ) were also made with a Li-Cor $(2 \pi)$ quantameter simultaneously with measurements of surface PAR (SPAR $2 \pi$ ) on the deck of the vessel in order to calculate the percentage of PAR at each level in the water column.

Salinity values of the CTD were calibrated against measurements made using a Guildline Autosal 8400 salinometer, (precision: \pm 0.001 ). For each surface station, and at all levels along the Loire-Vilaine transect, $125 \mathrm{~mL}$ were sampled and stored at $-20{ }^{\circ} \mathrm{C}$ on board. Nitrate+nitrite, phosphate and silicic acid concentrations were measured on a Technicon Auto Analyser II. 
For pigment analysis, $1 \mathrm{~L}$ seawater samples were pre-filtered through $200 \mu \mathrm{m}$ mesh nylon gauze and then filtered onto $25 \mathrm{~mm} \mathrm{GF/F} \mathrm{fibre} \mathrm{filters} \mathrm{under} \mathrm{low-pressure} \mathrm{vacuum}$ ( $<0.5$ bar, following Del Amo et al., 1997). Pigments were extracted and analysed by the reverse-phase HPLC method slightly modified from Wright et al. (1991). For each sample, $500 \mu \mathrm{L}$ of acetone-water extract were mixed with $165 \mu \mathrm{L}$ IP solution (tetrabutylammonium acetate buffered to the ammonium acetate) and $35 \mu \mathrm{L}$ of trans-canthaxanthin (internal standard) and $100 \mu \mathrm{L}$ were injected automatically by a refrigerated $\left(4^{\circ} \mathrm{C}\right)$ automatic sampler Thermo AS3000 in a ODS2 C18 column $(150 \mathrm{~mm} \times 4.6 \mathrm{~mm}$, with $3 \mu \mathrm{m}$ silica particles $)$. The Thermo UV3000 detector scanned the range spectrum between 400 and $700 \mathrm{~nm}$, and the effective detection was performed at $440 \mathrm{~nm}$.

The chemotaxonomy techniques have been applied to the results of the pigment analysis. As primary taxonomic markers, alloxanthin (allo), fucoxanthin (fuco), peridinin (peri), zeaxanthin (zea), 19'-hexanoyloxyfucoxanthin (19HF) and chlorophyll $b$ (Chl b) respectively are typical pigments of cryptophytes, diatoms, photosynthetic dinoflagellates, coccoid cyanobacteria, prymnesiophytes and "green algae" (Jeffrey, 1997).

The contribution of each phytoplankton group to the total biomass was determined with CHEMTAX program (Mackey et al., 1996).

\subsection{Phytoplankton observations from the REPHY}

Phytoplankton populations have been studied at two locations (Fig. 1) within the French Phytoplankton and Phycotoxins Monitoring Network (REPHY, http:// www.ifremer.fr/envlit/surveillance/rephy.htm). 
At sampling station "Men Du", surface seawaters are routinely collected every two weeks to obtain time series data and detect major events. When an event is detected, like in March 2000, sampling can become weekly or more frequent in this station and the adjacent one "Les Glénan". Each time, 2 bottles of sea water are sampled. One of them is used for microscopic observations on living cells, and the second one is fixed with lugol $\left(1 \mathrm{ml} \cdot \mathrm{L}^{-1}\right)$ for species enumeration.

Occasionally, phytoplankton samples are collected by hauls of 20 or $30 \mu \mathrm{m}$ mesh nets. Countings are performed by the Utermöhl method after sedimentation of 4 hours minimum in $10 \mathrm{ml}$ counting chambers and using an inverted light microscope fitted with 10X, 20X and 40X objectives and phase contrast optics.

\subsection{The chlorophyll concentration derived from SeaWiFS data}

Quantitative estimates of the chlorophyll- $a$ concentration at the surface were derived from SeaWiFS data. Thanks to these data, the space and time patterns of the bloom were particularly well observed from March 5 to 16.

The SeaWiFS scenes were processed with SeaDAS 4.0., the standard processing package provided by NASA. The basic data are the normalized water leaving radiances $\mathrm{L}_{\mathrm{nw}}$ at $412,443,490,510$ and $555 \mathrm{~nm}$. A look-up table (Gohin et al., 2002) was used to estimate the chlorophyll concentration in this mixed coastal-clear water area.The look-up table relates SeaWiFS triplets [OC4 maximum band ratio, $\mathrm{L}_{\mathrm{nw}}(412)$ and $\mathrm{L}_{\mathrm{nw}}(555)$ ] to chlorophyll concentration. The OC4 maximum band ratio is defined as the greatest reflectance ratio amongst $\mathrm{R}(443) / \mathrm{R}(555), \mathrm{R}(490) / \mathrm{R}(555)$, and $\mathrm{R}(510) / \mathrm{R}(555)$. The reflectance at wavelength $\lambda$ 
is derived from the normalized radiance by $R(\lambda)=$ Erreur !, where $F_{0}$ is the extraterrestrial solar irradiance.

In the review of chlorophyll algorithms for SeaWiFS by O'Reilly et al. (1998), the Ocean Color 4 channel algorithm yielded one of the best results after tuning to a common data set. In case 2 waters, due to absorption by the yellow substances (CDOM) and error in the SeaDAS atmospheric correction, the water leaving radiance and the reflectance are very often negative in the blue. Our look-up table is based on an empirical and regional parameterization of the OC4 levels as a function of $\mathrm{L}_{\mathrm{nw}}(412)$ and $\mathrm{L}_{\mathrm{nw}}(555)$. For a defined level of chlorophyll concentration, the $\mathrm{OC} 4$ ratio decreases conversely to $\mathrm{L}_{\mathrm{nw}}(412)$ and $\mathrm{L}_{\mathrm{nw}}(555)$. Very negative $412 \mathrm{~nm}$ - radiances are calculated by SeaDAS in river plumes contaminated by CDOM, or in case of continental atmospheres characterized by strongly absorbing aerosols. The $\mathrm{L}_{\mathrm{nw}}(555)$ dependency is mainly linked to the effect of the suspended matters, whose load can be relatively high in winter over the continental shelf, on the OC4 ratio.

\subsection{The sea surface temperature derived from AVHRR data}

The advanced very high resolution radiometer (AVHRR) is a broad-band scanner, sensing in the visible, near-infrared, and thermal infrared portions of the electromagnetic spectrum. The NOAA/AVHRR has three infra-red channels providing the brigthness temperature of the sea surface in three bands, channel $3(3.6-3.8 \mu \mathrm{m})$, channel 4 (10.2$11.2 \mu \mathrm{m})$, and channel $5(11.5-12.5 \mu \mathrm{m})$.

The sea surface temperature Ts can be obtained by a two channel algorithm : Ts $=\mathrm{T}_{4}$ $+2\left(T_{4}-T_{5}\right)+0.5$ where $T_{4}$ and $T_{5}$ are the brightness temperatures of the surface in the infrared channels 4 and 5. However, this combination increases dramatically the noise between 
pixels. At the scale of our coastal area, we can consider that the atmospheric effect is constant and add $2{ }^{\circ} \mathrm{C}$ to the brightness temperature at channel 4 to obtain a low-noise and realistic temperature field.

\subsection{The sea surface solar irradiance derived from METEOSAT data}

The solar irradiance in the $0.3-4.0 \mu \mathrm{m}$ band are calculated from METEOSAT-7 data (Brisson et al., 1994, 2001). The solar irradiance at the surface, $\mathrm{E}_{\mathrm{SOL}}(0)$, is inversely related to the planetary albedo A, at the top of Atmosphere, in the solar spectrum broadband.

$A$ is expressed as the sum of three terms : $A=A_{\text {ray }}+T_{1} A_{c}+A_{S} T_{2} T_{c}^{2} /\left(1-T_{b c} A_{s} A_{c}\right)$

$\mathrm{A}_{\text {ray }}$ is the Rayleigh albedo due to the molecules of the atmosphere, $T_{1}$ the sun-cloudsatellite transmittance, Ac the cloud albedo, As the surface albedo, $T_{2}$ the sun-surfacesatellite transmittance, $\mathrm{T}_{\mathrm{c}}$ the cloud transmittance, $\mathrm{T}_{\mathrm{bc}}$ the transmittance below cloud.

In (1), $1 /\left(1-\mathrm{T}_{\mathrm{bc}} \mathrm{A}_{\mathrm{s}} \mathrm{A}_{\mathrm{c}}\right)=\lim \left(1+\mathrm{T}_{\mathrm{bc}} \mathrm{A}_{\mathrm{s}} \mathrm{A}_{\mathrm{c}}+\left(\mathrm{T}_{\mathrm{bc}} \mathrm{A}_{\mathrm{s}} \mathrm{A}_{\mathrm{c}}\right)^{2}+\ldots\right)$ accounts for multiple scattering between the surface and the clouds.

The solar irradiance at the sea surface $\mathrm{E}_{\mathrm{SOL}}(0)$ is related to the surface and cloud albedos :

$\mathrm{E}_{\mathrm{SOL}}(0)=\mathrm{E}_{\mathrm{C}} \mathrm{v}(\mathrm{j}) \cos \left(\theta_{0}\right) \mathrm{T}_{0} \mathrm{~T}_{\mathrm{c}} /\left(1-\mathrm{T}_{\mathrm{bc}} \mathrm{A}_{\mathrm{s}} \mathrm{A}_{\mathrm{c}}\right)$

Where $E_{C}$ is a solar constant, $T_{0}$ the sun-surface atmospheric transmittance, $\theta 0$ is the sun zenith angle, and $v(\mathrm{j})$ is the corrective term accounting for the seasonal variation of the earthSun distance, $\mathrm{j}$ is the day of the year. 
The solar irradiance estimated from METEOSAT data is routinely checked by comparison to the observations of the French pyranometric network. Though it remains only a small mean bias after calibration on the whole set of data, the irradiance derived from METEOSAT may be underestimated in case of very sunny days by a factor of 5 to $8 \%$ (Anne Marsouin, personal communication). However, and despite their acknowledged bias in very sunny conditions, we have considered useful those data which are more appropriate than those of the continental meteorological stations which are too far from the studied area.

\subsection{Modeling the light available in the surface mixed layer}

The spectral diffuse attenuation $K(\lambda)$ is defined as the rate at which the natural logarithm of downwelling irradiance $\mathrm{E}(\lambda)$ at wavelength $\lambda$ is attenuated with depth.

Integrated over the PAR domain $(400-700 \mathrm{~nm}), \mathrm{K}_{\mathrm{PAR}}$ relates the downwelling spectral irradiance at depth $z, E_{P A R}(z)$, to the spectral irradiance just beneath the ocean surface, $\mathrm{E}_{\mathrm{PAR}}(0)$

$$
\operatorname{E}_{\text {PAR }}(z)=E_{\text {PAR }}(0) e^{-K_{P A R Z}}
$$

As in Riley (1957), we assume that the phytoplankton population in the water column of Zm meters depth is subjected to strong turbulence, so that the amount of light received by one cell approaches the mean amount of light in the water column $\overline{\mathrm{E}}_{\mathrm{PAR}}$.

$\overline{\mathrm{E}}_{\mathrm{PAR}}=$ Erreur $! \mathrm{E}_{\mathrm{PAR}}(0)$ 
Riley (1957) proposed a mean solar irradiance in the water column, $\overline{\mathrm{E}}_{\mathrm{SOL}}$, integrated over the solar irradiance band $(0.3-4.0 \mu \mathrm{m})$, of about $0.03 \mathrm{~g}$-cal $\mathrm{cm}^{-2} \mathrm{~min}^{-1}$, or $20.9 \mathrm{~W} \mathrm{~m}^{-2}$, critical for the initiation of a bloom in temperate waters. This critical value has been proposed by Riley only for regional comparisons because it is the irradiance restricted to the PAR domain which is significant in describing the effect of light on the photosynthesis.

$\mathrm{E}_{\mathrm{PAR}}$ is approximately linearly related to $\mathrm{E}_{\mathrm{SOL}}$ after considering the loss at the air-sea interface by reflectance (for solar radiance and diffuse sky radiance) and the ratio of irradiance in the PAR domain to total irradiance.

The reflectance at the surface is approximately 0.05 , and the ratio of PAR energy to total energy is equal to 0.425 (Jitts et al., 1976). Moreover, if $E_{\mathrm{PAR}}$ is expressed in mol quanta $\mathrm{m}^{-2} \mathrm{~d}^{-1}$, the conversion factor: $1 \mathrm{~mol}$ quanta $\mathrm{m}^{-2} \mathrm{~d}^{-1} 2.5 \mathrm{~W} \mathrm{~m}^{-2}$ has to be applied to the irradiance to obtain a value in $\mathrm{W} \mathrm{m}^{-2}$.

Despite its dependence on the environmental conditions, mainly the solar zenith angle and the depth, analyzed in Gordon (1989), the spectral attenuation coefficient $K(\lambda)$ is considered as a quasi inherent optical property of the water. Smith and Baker (1978) give the following set of equations to determine $K(\lambda)$ from the chlorophyll concentration $C$ for case 1 waters:

$$
\begin{array}{ll}
\mathrm{K}(\lambda)=\mathrm{K}_{\mathrm{w}}(\lambda)+\mathrm{k}_{1} \mathrm{C} & \text { for } \mathrm{C}<1 \mathrm{mg} \mathrm{m}^{-3} \text { (5) } \\
\mathrm{K}(\lambda)=\mathrm{K}_{\mathrm{w}}(\lambda)+\mathrm{K}_{\mathrm{X} 2}(\lambda)+\mathrm{k}_{2} \mathrm{C} & \text { for } \mathrm{C}>1 \mathrm{mg} \mathrm{m}^{-3} \text { (6) }
\end{array}
$$


$\mathrm{K}_{\mathrm{X} 2}$ is the contribution from material suspended or dissolved in the water not covarying with $\mathrm{C}$.

Fig. 2 shows the spectral $K(\lambda)$ obtained after applying these equations to some chlorophyll concentrations encountered in the bloom, using the spectral values of $\mathrm{k}_{1}, \mathrm{k}_{2}, \mathrm{~K}_{\mathrm{X} 2}$, and $\mathrm{K}_{\mathrm{w}}$ given in Smith and Baker (1978). For the long wavelengths, superior to $630 \mathrm{~nm}$, the coefficients $\mathrm{k}_{1}, \mathrm{k}_{2}$, and $\mathrm{K}_{\mathrm{X} 2}$, provided by Smith and Baker, do not assure an agreement between the $\mathrm{K}$ deduced from equations (5) and (6) when they are applied to a chlorophyll concentration of $1 \mathrm{mg} \mathrm{m}^{-3}$. Nevertheless, at those wavelengths, light is highly absorbed and an error in the evaluation has no significant effect on the estimation of the PAR.

\subsection{Modeling the nutrient consumption during the bloom}

To estimate the nutrients necessary to feed the bloom gwroth, we have to convert the chlorophyll concentration chl(t), which is the observed variable derived from SeaWiFS imagery, to carbon concentration and then apply the Redfield molar ratios, $\mathrm{C} / \mathrm{N} / \mathrm{P} / \mathrm{Si}=$ $106 / 16 / 1 / 16$ to the carbon concentration expressed in moles.

The cellular mass ratio of chlorophyll $a$ to carbon, $\mathrm{Chl}: \mathrm{C}$, can be estimated from an empirical formulation (Cloern et al.,1995) :

$$
\text { Chl : C }=0.03+0.0154 \mathrm{e}^{0.05 \mathrm{~T}} \mathrm{e}^{-0.059 \overline{\mathrm{E}}_{\mathrm{PAR}} \mathrm{f}_{\mathrm{N}}}
$$


Formulation (7) is applied to a phytoplankton population grown under temperature $\mathrm{T}$ $\left({ }^{\circ} \mathrm{C}\right)$, and daily irradiance $\overline{\mathrm{E}}_{\mathrm{PAR}}$ (mol quanta $\left.\mathrm{m}^{-2} \mathrm{~d}^{-1}\right)$, in condition of nutrient-limited growth, specified by the factor $f_{N}$. $f_{N}$ is described by the Monod equation: $f_{N}=N u /\left(K_{N u}+N u\right), K_{N u}$ being the half-saturation constant for the limiting nutrient $\mathrm{Nu}$.

The carbon concentration $\mathrm{C}(\mathrm{t})$, in mass, evolves with time following :

$$
C(t+\Delta t)=C(t)+\left(\mu f_{N}-m\right) C(t) \Delta t
$$

Where $\mu$ is the maximum daily growth rate, depending on the photosynthesis efficiency at ambient irradiance, and $\mathrm{m}$ is the loss rate due to grazing and sinking.

Simultaneously to the growth of the phytoplankton biomass, the nutrient concentration, in moles, evolves following :

$$
\mathrm{Nu}(\mathrm{t}+\Delta \mathrm{t})=\mathrm{Nu}(\mathrm{t})-\mu \mathrm{f}_{\mathrm{N}} \mathrm{C}(\mathrm{t}) \Delta \mathrm{t} \mathrm{R}(\mathrm{Nu}) / \mathrm{M}(\mathrm{C})
$$

Where $\mathrm{R}(\mathrm{Nu})$ is the Redfield molar ratio $[\mathrm{Nu}: \mathrm{C}]$ and $\mathrm{M}(\mathrm{C})$ is the atomic mass of carbon. The evolution of $\mathrm{Chl}(\mathrm{t})$ is related to $\mathrm{C}(\mathrm{t})$ by :

$$
\operatorname{Chl}(\mathrm{t}+\Delta \mathrm{t})=\operatorname{Chl}(\mathrm{t})-\mathrm{m} \operatorname{Chl}(\mathrm{t}) \Delta \mathrm{t}+\mu \mathrm{f}_{\mathrm{N}} \mathrm{C}(\mathrm{t}) \Delta \mathrm{t}[\mathrm{Chl}: \mathrm{C}](\mathrm{t}) \quad(\mathbf{1 0})
$$

From equations (4)-(10), we can formulate $\mathrm{K}_{\mathrm{PAR}}(\mathrm{t}),[\mathrm{Chl}: \mathrm{C}](\mathrm{t}), \mathrm{C}(\mathrm{t}), \mathrm{Chl}(\mathrm{t}), \mathrm{N}(\mathrm{t}), \mathrm{PO}_{4}(\mathrm{t})$, $\mathrm{S}_{\mathrm{i}}(\mathrm{OH})_{4}(\mathrm{t})$, from observed $\mathrm{Chl}\left(\mathrm{t}_{0}\right), \mathrm{N}\left(\mathrm{t}_{0}\right), \mathrm{PO}_{4}\left(\mathrm{t}_{0}\right)$, and $\mathrm{Si}(\mathrm{OH})_{4}\left(\mathrm{t}_{0}\right)$, where $\mathrm{t}_{0}$ is the time at the initiation of the bloom. 


\section{RESULTS}

\subsection{The chlorophyll concentration and the environmental conditions before the bloom}

The environmental conditions before the MODYCOT cruise show typical winter features. The flows of the Loire river in early march 2000 (Fig. 3) are higher than $2000 \mathrm{~m}^{3} \mathrm{~s}^{-1}$ with a short peak at $3000 \mathrm{~m}^{3} \mathrm{~s}^{-1}$ in February and a main peak at the beginning of January. South winds (Fig. 4) are dominant during the 30 days before the cruise, with a decrease in the mean speed during the first week of March (from 18 knots to 2 knots).

During the MODYCOT cruise, from March 1 to 6 , the surface chlorophyll $a$ concentration (Fig. 5) ranges between 0.2 and $1 \mathrm{mg} \mathrm{m}^{-3}$ and are typical winter values for that area. On transect $\mathrm{T} 4$, the higher chlorophyll concentrations $\left(\sim 0.70 \mathrm{mg} \mathrm{m}^{-3}\right)$ are observed in the middle of the transect, along the100-m isobath (Fig. 6).

The pigment chemotaxonomic analysis (Lampert, 2001) shows a clear dominance of the diatoms in the total phytoplankton biomass (Table 1).

The sea surface temperature is close to $10^{\circ} \mathrm{C}$ near the coast and reaches $11.5^{\circ} \mathrm{C}$ near the edge of the continental shelf (Fig. 5a). The salinities are respectively below 30 and 33 near the Gironde and Loire estuary (Fig. 5b). Haline fronts are well marked and are parallel to the coast. The 35 iso-salinity line follows approximately the $120 \mathrm{~m}$ isobath. However the stratification is far from homogeneous over the continental shelf. The vertical profiles of temperature, salinity, and nutrients along transect T4 are shown on Fig. 6 and the vertical profiles of temperature and salinity along transect T5 on Fig. 7 (unfortunately no nutrient profile was measured along transect T5). A relatively homogeneous surface layer of about 
$30 \mathrm{~m}$ depth exists on the major part of transect T5 (between Station 18 and 16); i.e. the area where the bloom will start after March 5, corresponding to water depth from 100 to $130 \mathrm{~m}$. The vertical distribution of nutrients along transect $\mathrm{T} 4$ shows the effect of the river inputs near the coast and the vertical mixing over the whole water column offshore.

From the profiles of light attenuation at $660 \mathrm{~nm}$ deduced from transmissiometry data (Fig. 8), the stratification appears to be higher along the northern transect T5 and the water a little bit clearer in the area which will host the future bloom.

Table 2 presents: a) the value of $K_{\mathrm{PAR}}$ measured during the day at stations 16 to 19 of transect $\mathrm{T} 4$, and stations 14 and 15 of transect $\mathrm{T} 5 ; \mathrm{b}$ ) the respective depths of the mixed layers, estimated by visual analysis of the density profiles, and c) the surface solar irradiance required to obtain a mean amount of light, $\overline{\mathrm{E}}_{\mathrm{SOL}}$, superior to Riley's critical value. $\overline{\mathrm{E}}_{\mathrm{SOL}}$ is calculated from formulation (4). Fig. 9 shows the satellite-derived solar irradiance over the Bay of Biscay during the bloom. Comparing the satellite-derived irradiance of about $150 \mathrm{~W} \mathrm{~m}^{-2}$, estimated on March 4, to the values noticed in Table 2, we observe that stations 17 and 18 are the only locations where a bloom could commence following Riley's hypothesis. Fig. 9b shows the concentration of suspended matters calculated from the water leaving radiance at $555 \mathrm{~nm}$ (Froidefond et al, 2002). High suspended matter concentrations are observed within the river plumes and along the coast. On Fig.9b, the area where the suspended matter concentration is greater than $1 \mathrm{~g} \mathrm{~m}^{-3}$ has proven to be unable to sustain any significant bloom in March 2000, except in the shallow waters of the Bay of Vilaine.

3.3 The chlorophyll concentration during the development of the bloom 
The phytoplankton bloom, revealed by the SeaWiFS imagery from March 5 to 16 (Fig. 10), appears to be a major event in the Bay of Biscay. Commencing on March 5, the bloom grows and extends shoreward (Fig. 11). On April 7 (Fig. 10), after a cloudy period of three weeks, the SeaWiFS image shows very different features on the continental shelf of South Brittany. The chlorophyll concentration is now lower in the area of the former bloom and higher in the north and closer to the coast. The Bay of Vilaine, subject to a constant flux of nutrients, appears to be still chlorophyll-rich, with higher concentrations than in the Loire or Gironde plumes which are too turbid at that time of the year.

\subsection{The phytoplankton observations from the REPHY network}

On February 21, at coastal station "Men Du", the microphytoplankton ( $>20 \mu \mathrm{m})$ with 18100 cells $\cdot \mathrm{L}^{-1}$ was mostly represented by diatoms with the main genera: Nitzschia, Navicula, Skeletonema, Pseudo-nitzschia, but also by dinoflagellates with the genus Scrippsiella.

On March 9, the microphytoplankton reached 27000 cells $\cdot \mathrm{L}^{-1}$. Diatoms and dinoflagellates were equitably present with the dominant taxa Pseudo-nitzschia pungens, Chaetoceros danicus, Nitzschia longissima and Cylindrotheca closterium for the first class, and Scrippsiella sp. for the second one.

On March 15, a fisherman brought to the Concarneau IFREMER laboratory some greenish silt sampled from his fishing nets, cast in the studied area, for microscopic examination. The analyzes showed the presence of diatoms and dinoflagellates. A chemical analysis of this greenish silt revealed that it was composed of water and polysaccharides 
(more than $70 \%$ of organic matter). Its presence in nets was reported by fishermen up to early April.

On March 16 at stations "Men Du" and "Les Glénan", a bloom of nanoplankton (Fig. 12) accompanied by auto- and heterotrophic dinoflagellates, euglenophytes, and some large Coscinodiscus was detected. An haul at station "Les Glénan" displayed the presence of numerous large discs of this diatom Coscinodiscus responsible for the mucilage clogging the nets. Nanoplankton was characterized by a large diversity of prymnesiophytes with the genus Chrysochromulina, and coccolithophorids, identified by the University of Caen as Crystallolithus hyalinus, Emiliania huxleyi, Acanthoica quattrospina, Alisphaera unicornis, Syracosphaera sp., and also cryptophytes with the genus Plagioselmis, and chrysophytes with the species Apedinella spinifera.

On March 20, at station "Men Du", the phytoplankton population was always dominated, in number, by nanoflagellates ( $98 \%$ ), while the microphytoplankton (33100 cells $\cdot \mathrm{L}^{-1}$ ), with a majority of dinoflagellates, always contained large Coscinodiscus.

The chlorophyll concentration evolves from 1.12 (March 9) to 3.28 (March 20) and $1.17 \mathrm{mg} / \mathrm{m}^{-3}$ (April 3). Though we have no measurement of the relative contribution of each species to the total biomass, the bloom of March 20 can be attributed to Coscinodiscus rather than to nanoflagellates. The biovolume of a cell of $C$. wailesii (about $280 \mu \mathrm{m}$ of diameter and $215 \mu \mathrm{m}$ of thickness) is several orders of magnitude higher than that of a nanoflagellate.

The nanoplankton bloom lasted up to late April while a vertical haul in "Les Glénan" on April 6 let to announce the end of the development of Coscinodiscus with numerous frustules of the major species C. wailesii ( $80 \%$ of the total frustules of Coscinodiscus). 
We can now propose a scenario for the development of the bloom supported by both satellite and in situ sets of data. The bloom developed initially offshore, commencing on March 5, and reached Les Glenan on March 16. Then the phytoplankton population decreased offshore while increasing inshore.

3.5 The satellite-derived sea surface temperature, as an indicator of the hydrological situation, compared to the chlorophyll distribution

The satellite temperature maps derived from the AVHRR aboard NOAA 14 and NOAA 15, show clearly the oceanic/coastal interface line along the 120 -m isobath (Fig. 13). The series of temperature maps (Fig. 13b-d) over the bloom area show a mean increase in temperature, fluctuating with the AVHRR acquisition time in the day, and a stable gradient from coast offshore through the whole period. The chlorophyll concentration images show that the bloom area is restricted to the clear and stratified waters already identified during the MODYCOT cruise. The coastal area, bounded by the tiny coastal line, where is located the "Men Du" station, and the 60-m isobath, appears to be chlorophyll-poor in comparison with the bloom area, extending from "Les Glenan" offshore. The stable SST patterns suggest that the hypothesis set up from the observations of the MODYCOT cruise are still appropriate. The mean light in the surface layer is the limiting factor which does not permit a strong growth of the phytoplankton outside of the clear and stratified area identified during the MODYCOT cruise. The vertical profiles in temperature, salinity, and the attenuation coefficient $\mathrm{K}_{660}$ shown on Fig.7a-b and Fig.8a indicate that stations 16 to 18 of transect T5 belong to that area which is bounded offshore by poorly stratified water and inshore by coastal waters which are not clear enough to permit the initiation of a bloom. On Fig.13b are shown two sets of pixels selected from their location within the bloom. The western set of 
pixels refers to the offshore area. This offshore part of the bloom is bordered, on its western side, by the salinity front. The second set is part of the inshore area which is bounded, on the east, by more turbulent and more turbid coastal waters. These waters, which extend from the 60-m isobath onto the coast, appear colder on the AVHRR image of March 16 (Fig. 13d). Fig.13c and $\mathrm{d}$ show the shift in time between the early offshore bloom and the delayed development inshore.

3.6 The light availability during the development of the bloom

To calculate the mean amount of light $\overline{\mathrm{E}}(\lambda)$, in the $\lambda$ band, integrated over the mixed surface layer, the spectral attenuation coefficient $K(\lambda)$ is applied in equation (4) in place of $\mathrm{K}_{\mathrm{PAR}}$.

Then, $\overline{\mathrm{E}}_{\mathrm{SOL}}$ is calculated by integrating $\overline{\mathrm{E}}(\lambda)$ over the [400-630] $\mathrm{nm}$ band, considering that the solar irradiance observed at the surface is uniformly distributed over this domain.

Without correcting for the loss at the air-sea interface, $\overline{\mathrm{E}}_{\mathrm{SOL}}$, expressed in $\mathrm{W} \mathrm{m}{ }^{-2}$, can be compared to Riley's critical value.

Fig. 14 shows the daily solar surface irradiance derived from METEOSAT and the chlorophyll concentration during the development of the bloom in the inshore and offshore areas. The series of mean irradiance, $\overline{\mathrm{E}}_{\text {SOL }}$ integrated over the $30 \mathrm{~m}$ mixed layer, is shown on Fig. 15, together with mean $\mathrm{K}$ in the [400-630] nm band calculated on the offshore area after applying formula (5) and (6) to daily chlorophyll concentrations interpolated from the 
observed data indicated on Fig. 14. The daily chlorophyll concentration increases from 0.5 (onset of the bloom) to $6 \mathrm{mg} \mathrm{m}^{-3}$ (full development phase of the bloom). The initial value of $\mathrm{K}, 0.13 \mathrm{~m}^{-1}$, estimated from the formula of Smith and Baker for clear water, is very close to that observed during the MODYCOT cruise in the PAR band $\left(0.15 \mathrm{~m}^{-1}\right.$ at station 16$)$. In the last phase of the bloom, from March 12 to 16, the mean irradiance calculated in the upper mixed layer is low but still very close to the critical value proposed by Riley. Considering that the METEOSAT irradiance is underestimated by a factor of about $7 \%$ during these very sunny days, the difference between Riley's value and the mean irradiance integrated over the surface layer is not significant.

\subsection{The nutrient control on the phytoplankton growth}

The high level in chlorophyll concentration observed in the bloom area cannot be obtained without a significant consumption of nutrients.

The increase in chlorophyll concentration and the related consumption in nutrients are calculated by formulations (7)-(10).

Calculated from equation (7), where $E_{P A R}(t)$ is replaced by $E_{P A R}$ averaged over the two preceding days, $[\mathrm{C}:$ chl] ratio is about 50 . during the first phase of the bloom development and increases inversely to $\mathrm{f}_{\mathrm{N}}$.

The initial nutrient concentrations $\left(\mathrm{N}\left(\mathrm{t}_{0}\right), \mathrm{P}\left(\mathrm{t}_{0}\right), \mathrm{Si}\left(\mathrm{t}_{0}\right)\right)$ have been considered equal to $(9,0.33,6)$, and $(12,0.35,9) \mu \mathrm{M}$, for the offshore and inshore area respectively, in accordance with the MODYCOT measurements (Fig. 5). $\mathrm{K}_{\mathrm{Nu}}$ used to calculate $\mathrm{f}_{\mathrm{N}}$ are given 
by Labry et al. (2001); $\mathrm{K}_{\mathrm{Nu}}$ are equal to $0.5,00.1$, and $2 \mu \mathrm{M}$ for nitrate, phosphate, and silicate respectively; $\mathrm{m}$ is equal to $0.07 \mathrm{~d}^{-1}$ at $10^{\circ} \mathrm{C}$, as in Loyer (2001).

Several values of the offshore and inshore daily growth rates $\mu$ have been tested by fitting the chlorophyll concentration curve to the satellite-derived concentrations. Finally, setting $\mu$ equal to 0.7 and $0.4 \mathrm{~d}^{-1}$, for the offshore and inshore area respectively, gives the curves shown on Fig. 16 (a).

Though large uncertainties in the initial nutrient concentrations at the exact location of the bloom, and many approximations in the formulation of the phytoplankton growth, the calculated curves shown on Fig.16 fit the chlorophyll concentration deduced from the SeaWiFS data. The chlorophyll concentrations deduced from SeaWiFS are also subject to errors which are not easily quantifiable. However, this series of satellite data appears to be of an exceptional quality because they concern case 1 waters observed in condition of stable atmosphere. Except for the image of March 15, obtained with a high satellite zenith angle, the concentrations deduced from SeaWiFS image can be considered as very reliable.

It results from the calculation that the offshore and inshore areas were phosphate depleted on March 12 and 17 respectively. The growth rate is much lower for the inshore area, 0.4 compared to 0.7 , which reflects the better light efficiency in the photosynthesis for the offshore area which is well stratified, clearer, and warmer than the inshore area. 


\section{Discussion}

The meteorological and hydrological conditions during the two first weeks of March 2000 show a favorable evolution for the development of a phytoplankton bloom: a) the high river flows during February create a shallow haline stratification, b) the incident light at the sea surface is high, giving the opportunity to initiate phytoplankton growth, c) the nutrient concentrations are elevated at the onset of the bloom.

Therefore, unlimited in nutrients in its initial phase, the bloom was triggered by the high solar irradiance. However, the attenuation coefficient increased from March 5 to 16, in relation with the scattering induced by the phytoplankton cells. We have seen that, in spite of this major increase in the attenuation coefficient, the phytoplankton bloom grew until total consumption of the phosphate inshore. Riley's approach is based on the hypothesis that the phytoplankton population is homogeneously distributed over depth. Such an hypothesis is often verified in the initiation of blooms, particularly in late winter when the turbulence is still high. While the plankton population grows, the situation begins to change. The profile of the attenuation coefficient, $\mathrm{K}$, partly follows the profile of the phytoplankton population which develops faster at the surface as the production rate is related to light. A formulation of the partial differential equations governing the phytoplankton distribution over depth and time can be found in the growth-diffusion model proposed by Huisman et al. (1999). In their model, the combination of light induced growth, local phytoplankton losses, and local transport of the cells by turbulent diffusion generates a stationary inhomogeneous vertical distribution of the phytoplankton population. The depth profiles of this steady-state phytoplankton populations show realistic patterns with a surface-bottom gradient steeper in less turbulent waters. It is likely that this stratification permits a better use of the light than 
that of a pure random distribution of the phytoplankton population within the mixed layer. Our observations concerning the effect of the light on the daily growth rate, through a differentiation of the bloom area into two characteristic zones marked by better stratification and clearer waters offshore, reinforce the role of the light in the phytoplankton growth. Though we have observed two different growth rates corresponding to different hydrological situations, we have not attempted to estimate the parameters of the photosynthesis-light equation because our knowledge of the hydrological situations, particularly onshore, was too poor at the time of the bloom. We have assumed that the hydrological situation in the bloom area was equivalent to that observed along transect T5; this is grossly acceptable but not sufficient to enable us to derive a pertinent estimation of the parameters of the growth curve. However, the local growth rates derived from SeaWiFS chlorophyll maps are realistic and these data could complement the small set of data available at that period on that area. A last comment on the utilization of light will concern the possible recurrence of a winter bloom. The solar irradiance within the mixed layer observed on March 5 is much higher than Riley's critical value (Fig. 15), and it is likely that the bloom could have occurred earlier if the meteorological condition would had been more favorable.

Fresh water extension of large rivers in the Bay of Biscay constitutes an important physical forcing which radically modifies the nutrient and light conditions of the oceanic environment. The physical regulation of phytoplankton blooms by river flow-induced haline stratification, has previously been shown in coastal (Erga \& Heimdal 1984, Levasseur et al. 1984, Thórdardóttir 1986) and estuarine waters (Cloern 1984, Ingram et al. 1985, Pennock \& Sharp 1994). The role of haline stratification is also clearly confirmed in these early bloom developments. A similar mechanism was described by Warren (1983) in the North Pacific where a strong haline stratification allows phytoplankton to develop throughout the winter; 
nevertheless the haline stratification in this case is not related to fresh water input, but is due to the surface circulation relatively closed to the input of high salinity water from the tropics, and to a lower evaporation rate in the Pacific than in the Atlantic. In the Bornholm Sea (Baltic Sea) Bodungen et al. (1981) also showed that the onset of the bloom occurred prior to the advent of thermal stratification, and was concomitant with haline stratification, calm weather, and cloudless sky. The recurrent appearance of a late winter-early spring bloom would be very similar to what is observed over the Georges Bank (Townsend and Thomas, 2001), though in that case the winter-spring bloom is not a consequence of a haline stratification but is determined by the bathymetry which creates a shallow mixed layer where the mean irradiance can reach Riley’s critical value as soon as February.

Though the bloom is initiated and controlled by light, the nutrients will be the limiting factor. Within seven days offshore and ten days inshore, the consumption of phosphate is quasi complete and the area is silicate depleted offshore. To have an idea on the magnitude of the bloom participation in the nutrient cycle of this part of the continental shelf of the Bay of Biscay, we can attempt to compare its consumption to the river nutrient loads.

For nutrient $\mathrm{Nu}$, the bloom consumption, $\mathrm{C}(\mathrm{Nu})$ in $\mathrm{g}$, can be estimated by :

$$
\mathrm{C}(\mathrm{Nu})=\mathrm{SZm} \Delta(\mathrm{Nu}) \mathrm{M}(\mathrm{Nu}) 10^{3}
$$

where $\mathrm{S}$ is the surface of the bloom in $\mathrm{m}^{2}, \mathrm{Zm}$ is the mixed layer depth in $\mathrm{m}, \Delta(\mathrm{Nu})$ is the variation in mole concentration calculated during the bloom, and $\mathrm{M}(\mathrm{Nu})$ is its atomic mass. 
The area of the bloom S can be estimated by counting the number of the pixels where the chlorophyll concentration was above $3 \mu \mathrm{g} / 1$ on March 12 or 16 . This number of pixels is equal to 5113 . On those pixels the mean chlorophyll concentration is $5.51 \mathrm{mg} / \mathrm{m}^{3}$ which is similar to the chlorophyll level reached on our simulation and shown on figure 16 . Thus, we may consider that, on this surface $\mathrm{S}$, the bloom consumed the totality of the phosphorus in the surface layer. As the size of the pixel is $1.1 * 1.1 \mathrm{~km}^{2}$, the surface $\mathrm{S}$ of the bloom is equal to $6187 \mathrm{~km}^{2}$. The total exhaustion of $\mathrm{P}_{4}$, evaluated to $0.34 \mu \mathrm{M}$, between March 5 and 17 is linked to a consumption of $5.44 \mu \mathrm{M}$ of $\mathrm{NOx}$ and $\mathrm{Si}(\mathrm{OH})_{4}$ after application of the Redfield ratios.

Considering that the depth $\mathrm{Zm}$ is approximately $30 \mathrm{~m}$, the bloom consumption of phosphorus and nitrogen (atomic masses of 31 and $14 \mathrm{amu}$ ) deduced from (11) is respectively around 1915 and 13837 t. Although the bloom growth was supplied by nutrients from both riverine and oceanic origin, its significance can be measured by comparison to the mineral phosphorus and nitrogen yearly discharged by both Loire and Vilaine rivers, 4200 and $153000 \mathrm{t}$ respectively (Loyer, 2001).

In 2000, the pigment chemotaxonomic analysis applied to MODYCOT data (Table 1), just before the onset of bloom, completed by phytoplankton observations in the coastal waters when the bloom was growing, led to assert that the phytoplankton biomass was mainly represented by diatoms. The REPHY phytoplankton counts suggest that this diatom population was dominated by large Coscinodiscus (diameter between 280 and $370 \mu \mathrm{m}$ ) with C. wailesii as dominant species. The capacity of this species to produce extracellular mucilage would explain the silt on fishing nets. However, the greenish colour could be related to euglenophytes and high concentrations (up to 10 millions cells $\cdot \mathrm{L}^{-1}$, on the 3 April) of 
nanophytoflagellates $(<20 \mu \mathrm{m}$ size fraction) which could have played a part in the agglomeration of discs of Coscinodiscus.

Similar results were observed in the winter bloom of the Gironde plume in 1998: the contribution of phytoplankton $>20 \mu \mathrm{m}$ ranged from 50 to $80 \%$ of total Chlorophyll $a$. Species enumeration in this size fraction of surface waters showed the dominance of diatoms; Coscinodiscus sp. with some Nitzschia sp., Thalassionema sp., Thalassiosira sp., Rhizosolenia sp., and Ditylum sp. (Labry et al., 2001). In 1999, diatoms were again the dominant phytoplankton group with Leptocylindrus sp., Thalassiosira sp.. and Skeletonema sp. as the dominant taxons. (Labry, 2001).

Such a winter diatom bloom may have consequences on the nature and importance of the phytoplankton populations appearing later in spring in the same area. For example, the hydrological and biological observations obtained during the cruise PEL2000, which started on April 16 2000, lead to the conclusion that the late winter bloom had dramatic influences on the nutrient content, the chlorophyll concentration, and the taxonomic composition of phytoplankton in the water column: $\mathrm{PO}_{4}$ was totally exhausted, chlorophyll $a$ values were the lowest on the whole shelf, and phytoplankton was dominated by small sized phytoplankton (Delmas et al., 2002). Even if water masses may have been partially renewed by advection, and therefore make questionable any comparison, the importance of the contrast between the two situations at such a scale allows to hypothesize a causal link between the second and the first situation. 
For the most significant part of Bay of Biscay, the spring blooms appear strongly limited by phosphate depletion and dominated by small sized phytoplankton which is grazed, and potentially controlled, by microzooplankton (Labry et al., 2001; Sautour et al., 2000). In North Pacific waters, Boyd et al. (1995) mention that because of winter phytoplankton production, the microzooplankton is ready and able to prevent the buildup of spring phytoplankton biomass. In the Bay of Biscay, the satellite observations available during spring (April-May 2000, not shown) reveal that the maximum of surface phytoplanktonic biomass is restricted to the coastal zone, mainly into the Vilaine, Loire and Gironde plumes, owing to stratification, continuous local nutrient inputs, and coastal turbidity lowering due to the decrease of river flow in time of high solar irradiance.

\section{Conclusion}

Satellite observations during March 2000 give a clear confirmation that late winter phytoplankton blooms occur in the Bay of Biscay as previously pointed out by Morin et al. (1991), and Labry et al. (2001). Recent studies have shown increased values in chlorophyll $a$ concentrations in the same zone in late February 1999 (Labry, 2001). Then, the present late winter phytoplankton bloom in the northern Bay of Biscay is the third direct observation of a winter phytoplankton bloom in large river plumes of the French coast during three consecutive years $(1998,1999,2000)$. It is also the most significant by the concerned area. Moreover, if we take into account that winter blooms have been supposed in the Gironde plume waters in 1994 and 1995 from total phosphate exhaustion in the mixed layer and anomalous spring phytoplankton characteristics (Herbland et al., 1998) it appears that winter 
blooms would occur 5 years out of 7 since 1994. Therefore, we can infer that these winter events would be more the rule than an exception in these waters.

The development of a late winter bloom has a major effect on the feature of spring phytoplankton production in the shelf waters. Our simple calculation shows that, by mid March 2000, phosphate and silicate are limiting or almost limiting offshore (between the 130 and $80-\mathrm{m}$ isobaths), phosphate is limiting onshore. For shallower waters, light is the essential factor in the control of local blooms. More studies have to be carried on to know whether a significant production could be observed later in the year and explained by recycling or advection of nutrients. The first available SeaWiFS in early April show that the former bloom area, contrary to surrounding waters, is unable to sustain a chlorophyll bloom.

The satellite imagery gives us a synoptic view over phytoplankton blooms, and appears very useful to describe the timing and the extent of the blooms which are often difficult to monitor by oceanographic cruises. The concomitance of a cloudless sky (indispensable for satellite imagery) with an increase of available light (enhancing winter phytoplankton growth) probably allows the observation of the majority of these winter blooms. However, a light amount sufficient to initiate a bloom is also likely to occur in presence of fine stratus, preventing use of the satellite color techniques. More studies are required to evaluate the potential of the METEOSAT solar irradiance fluxes to monitor these favorable climatic conditions and evaluate their effect on the chlorophyll and nutrient contents of the mixed surface layer from past and future cruises at sea. 
In case of noxious blooms producing for example mucilage, satellite observations offer useful possibilities for evaluating the location and extent of the impacted area; these satellite data, linked with species determinations carried out by in situ sampling, can be used without delay to warn fishermen about the risk of damaging fishing gear in situations of difficult trawling.

The area where the bloom occurred corresponds approximately to the position of the "Grande Vasière", characterized by the presence of mud, "vase", mixed with sand at the bottom. It is a very important fishing place and the question arises whether the early occurrence of blooms plays a major role in energy transfer within the food web. Are early blooms playing a decisive role in the feeding of the rich benthic population of the "Grande Vasière", in quantity and in time? How the succession of deeper blooms and the renewal of nutrients by advection, occurring later in the year, contribute to regulate the growth of this population?

\section{Acknowledgements:}

The authors would like to thank the SeaWiFS Project and the Distributed Active Archive Center at the Goddard Space Flight Center, Greenbelt, MD 20771, for the production and distribution of the SeaWiFS data acquired at the Dundee station. We are also indebted to NASA for providing the SeaDAS software. We are extremely grateful to METEO-FRANCE for the AVHRR and METEOSAT data provided through SATMOS (Service d'Archivage et de Traitement Météorologique des Observations Spatiales) and the SAF (Satellite Application Facility project) Ocean and Ice of EUMETSAT in Lannion. We also thank Guy Bodennec for 
his help in the analysis of the green silt which was proven to be due to Coscinodiscus wailesii, Thierry Labasque for providing observations from Modycot, Daniel Delmas for his advice on the consequences of the winter blooms, and Alain Menesguen for his constructive comments on the draft of this text. The authors also thank Olivier Archer for providing useful tools to visualize the satellite images, and the Caen University for scanning electron microscopy images. 


\section{REFERENCES}

Boalch, G. T., Harbour, D. S., 1977. Unusual diatom off the coast of south-west England and its effect on fishing. Nature 269, 687-688.

Bodungen B,V., Broeckel, K. V., Smetacek, V., Zeitschel, B., 1981. Growth and sedimentation of the phytoplankton bloom in the Bornholm Sea (Baltic Sea). In Lower Organisms and their Role in the Food Web, $15^{\text {th }}$ European Marine Biology Symposium, Kiel, Sept. 1980. Rheinheimer G., Fluegel H., Lenz J., Zeitschel B. eds. N5 pp 49-60.

Boyd, P. W., Strom, S., Withney, F. A., Doherty, S., Wen, M. E., Harrison, P. J., Wong, C. S., Varela, D.E. ,1995. The N.E. subarctic Pacific in winter: 1. Biological standing stocks. Marine Ecology Progress Series 128, 11-24.

Brisson, A., Le Borgne, P., Marsouin, A., Moreau, T., 1994. Surface irradiance calculated from Meteosat sensor during SOFIA-ASTEX, International Journal of Remote Sensing, 15, 197-203.

Brisson, A., Le Borgne, P., Marsouin, A., 2001. Ice SAF Surface Solar Irradiance Product Manual, Version 1.0 June 2001, Météo-France/DP/CMS, 22302 Lannion.

Cloern, J.E., 1984. Temporal dynamics and ecological significance of salinity stratification in an estuary (South San Francisco Bay, U.S.A.). Oceanologica acta, 7, 137-141.

Cloern, J.E., Grenz, C., Vidergar-Lucas, L., 1995. An empirical model of the phytoplankton chlorophyll : carbon ratio - the conversion factor between productivity and growth rate, Limnology and Oceanography, 40, 1313-1321. 
Delmas, D., Herbland, A., Pastoureaud, A, 2002. Driving forces and main characteristics of the winter-spring phytoplankton on the french continental shelf of the Bay of Biscay. Poster presented at the $8^{\text {th }}$ International Symposium of Oceanography of the Bay of Biscay; Gijon, Avril 2002.

Erga, S.R., Heimdal, B.R., 1984. Ecological studies on the phytoplankton of Korsfjorden, western Norway. The dynamics of a spring bloom seen in relation to hydrological conditions and light regime. Journal of Plankton research, 6, 67-90.

Froidefond, J.M., Lavender S., Labordes P., Herbland A., Lafon V., 2002, SeaWiFS data interpretation in a coastal area in the Bay of Biscay, International Journal of Remote Sensing, 23, 881-904.

Gohin, F., Druon, J.N., Lampert, L., 2002, A five channel chlorophyll concentration algorithm applied to SeaWiFS data processed by SeaDAS in coastal waters, International Journal of Remote Sensing, 23, 1639-1661.

Gordon, H.R., McCluney, W.R., 1975. Estimation of the depth of sunlight penetration in the sea for remote sensing, Applied Optics, 14(2), 413-416.

Gordon, H.R., 1989. Can the Lambert-Beer law be applied to the diffuse attenuation coefficient of ocean water?, Limnology and Oceanography, 34(8), 1389-1409. 
Huisman, J., Van Oostveen, P., Weissing, F.J., 1999. Critical depth and critical turbulence:Two different mechanisms for the development of phytoplankton blooms, Limnology and Oceanography, 44(7), 1781-1787.

Ingram, R.G., Legendre, L., Simard, Y., Lepage, S., 1985. Phytoplankton response to freshwater runoff: the diversion of the Eastmain River, James Bay. Canadian Journal of Fisheries and Aquatic Sciences, 42, 1216-1221.

Jeffrey, S.W., 1997. Application of pigment methods to oceanography. In: Jeffrey, S.W., Mantoura, R.F.C., Wright, S.W. (Ed), Phytoplankton pigments in oceanography. UNESCO, Paris, 127-166.

Jitts, H.R., Morel, A., Saijo, 1976. The relation of oceanic primary production to available photosynthetic irradiance, Australian Journal of Marine and Freshwater Research, 27, 441454.

Labry, C., Herband, A., Delmas, D., Laborde, P., Lazure, P., Froidefond, J.M., Jegou, A.M., Sautour, B. , 2001. Initiation of winter phytoplankton blooms within the Gironde Plume waters in the Bay of Biscay, Marine Ecology Progress Series, 212: 117-130.

Labry, C., 2001. Dynamique du phosphore et rôle comme facteur limitant de la production planctonique dans le panache de la Gironde sur le plateau continental Sud Gascogne. Thèse de Doctorat de l'Université de la Méditerranée, 155p. 
Lampert, L., 2001. Dynamique saisonnière et variabilité pigmentaire des populations phytoplanctoniques dans l'Atlantique Nord (Golfe de Gascogne). Thèse de Doctorat de l’Université de Bretagne Occidentale, Brest, 294 p.

Levasseur, M., Therriault, J.C., Legendre, L., 1984. Hierarchical control of phytoplankton succession by physical factors. Marine Ecology Progress Series, 13, 211-222.

Longhurst, A.,1998. Ecological geography of the sea, Academic Press, San Diego, 385p.

Loyer, S., 2001. Modélisation de la production phytoplanctonique dans la zone côtière atlantique enrichie par les apports fluviaux, Thèse de Doctorat de l'Université de Paris VI, $232 p$.

Mackey, M.D., Mackey, D.J., Higgins, H.W., Wright, S.W., 1996. CHEMTAX - a program for estimating class abundances from chemical markers: Application to HPLC measurements of phytoplankton, Marine Ecology Progress Series, 144: 265-283.

Morin, P., Le Corre, P., Marty, Y., L’Helguen, S., 1991, Evolution printanière des éléments nutritifs et du phytoplankton sur le plateau continental armoricain (Europe du Nord-Ouest). Oceanologica Acta 14:263-279.

O'Reilly, J. E., Maritorena, S., Mitchell, B.G., Siegel, D.A., Carder, K.L., Garver, S.A., Kahru, S.A., Mc Claim, C., 1998, Ocean color chlorophyll algorithms for SeaWiFS, Journal of Geophysical Research, VOL. 103, NO. CII, PAGES 24,937-24,953. 
Pennock, J.R., Sharp J.H., 1994. Temporal alternation between light- and nutrient-limitation of phytoplankton production in a coastal plain estuary. Marine Ecology Progress Series, 111, 275-288.

Riley, G.A., 1957. Phytoplankton of the North Central Sargasso Sea, Limnology and Oceanography, 2:252-270.

Rincé, T., Paumier, G., 1986. Données nouvelles sur la distribution de la diatomée marine Coscindiscus wailesii Gran\&Angst (Bacillariophyceae), Phycologia, 25 (1), 73-79.

Sautour, B., Artigas, L.F., Delmas, D., Herbland, A., Laborde, P., 2000, Grazing impact of micro- and mesozooplankton during a spring situation in coastal waters off the Gironde estuary. Journal of Plankton Research, 22, 531-552.

Smith, R.C., Baker, K.S., 1978. Optical classification of natural waters, Limnology and Oceanography, 23, 260-267.

Sverdrup, H.U. , 1953, On condition for the vernal blooming of phytoplankton, Journal du Conseil Permanent International pour l'Exploration de la Mer, 18:287-295.

Thórdardóttir, T., 1986. Timing and duration of spring blooming south and southwest of Ireland. In Skrelet S (ed) The role of freshwater outflow in coastal marine ecosystems, Springer-Verlag, Berlin, 345-360. 
Townsend, D.W., Thomas, A.C., 2001. Winter-spring transition of phytoplankton chlorophyll and inorganic nutrients on Georges Bank, Deep-Sea Research II, 48, 199-214.

Utermohl H., 1958. Zur vervolkommnung der quantitativen phytoplankton methodik, Mitteilungen-Internationale Vereiningung fur Limnologie, 9: 1-38.

Warren, B., 1983. Why is no deep water formed in the North Pacific?, Journal of Marine Research 41, pp 327-347.

Wright, S.W., Jeffrey, S.W., Mantoura, R.F., Llewellyn, C.A., Bjoernland, T., Repeta, D., Welschmeyer, N., 1991. Improved HPLC method for the analysis of chlorophylls and carotenoids from marine phytoplankton., Marine Ecology Progress Series, 77, 183-196. 


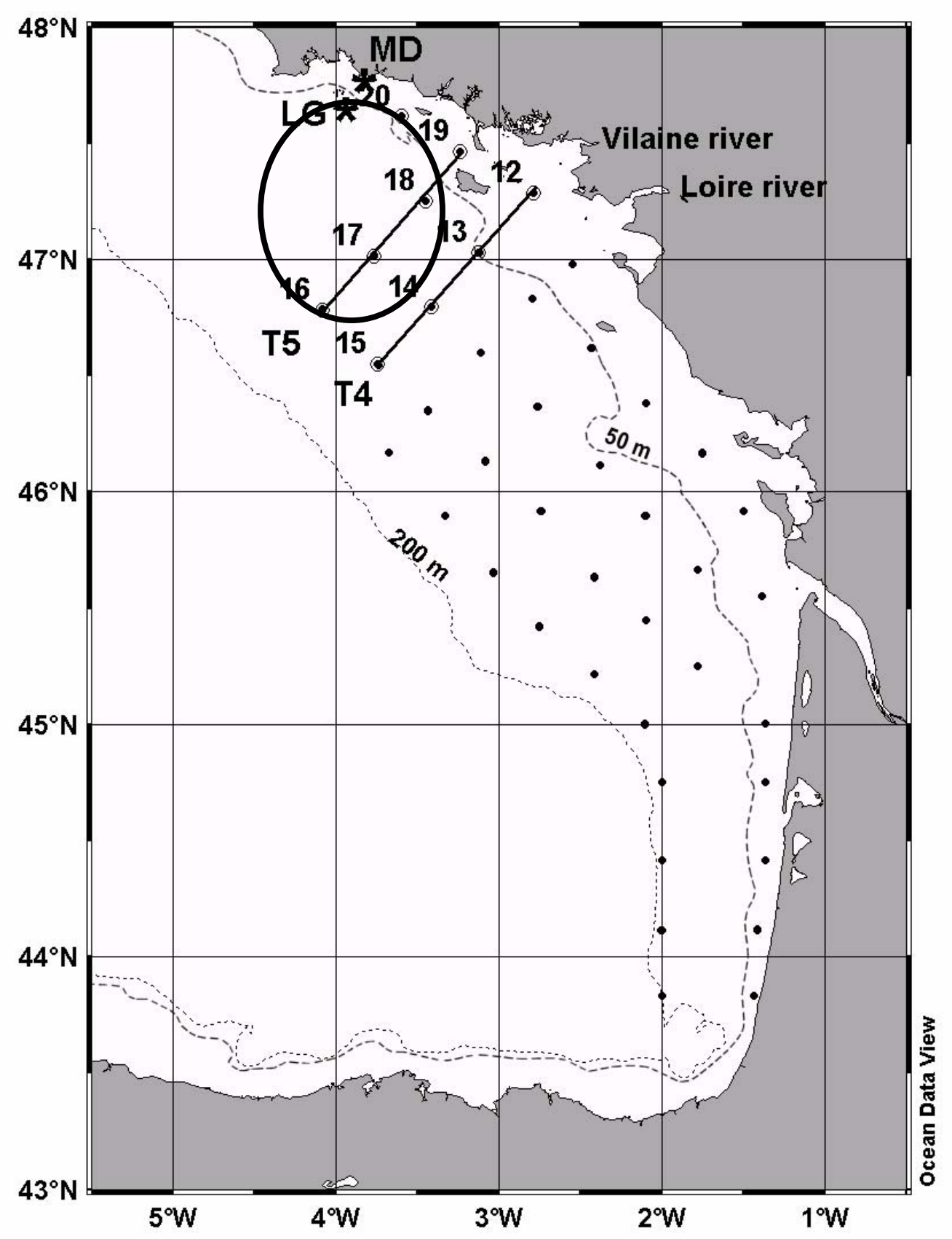

Fig. 1 : The 41 stations of the network sampled during the MODYCOT 2000 cruise (1-6 March 2000). The transects T5 (stations 16, 17, 18 and 19) and T4 (stations 12, 13, 14 and 15) are drawn. The approximated shape of the bloom area is shown by an ellipse. The two sites of the REPHY phytoplankton network in southwestern Brittany, MD (Men Du) and LG (Les Glénan) are also located on the map. 


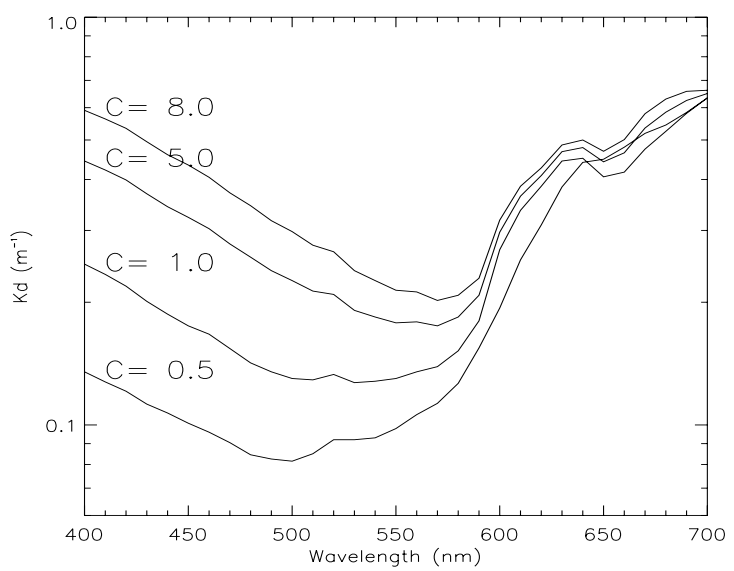

Fig.2: The spectral curves of the attenuation coefficient for some typical chlorophyll concentration, $\mathrm{C}$ in $\mathrm{mg} \mathrm{m}^{-3}$, encountered within the bloom. The curves are deduced from Smith and Baker's formulation. 


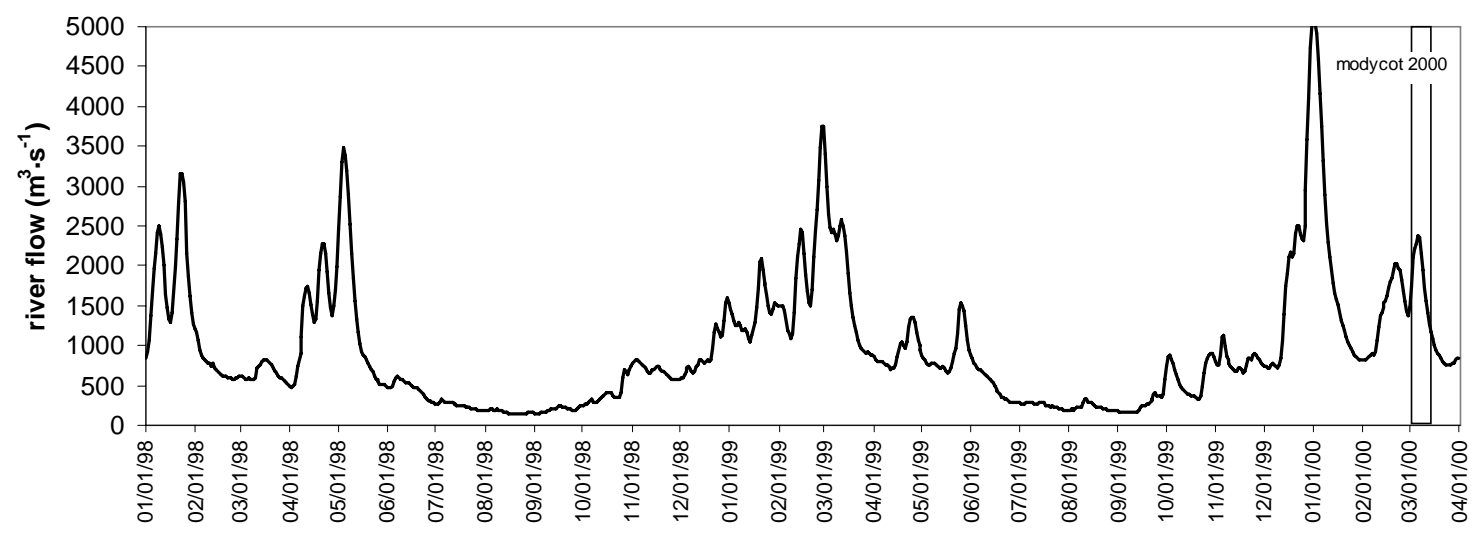

Fig. 3 : Flows of the Loire river from January 1998 to April 2000
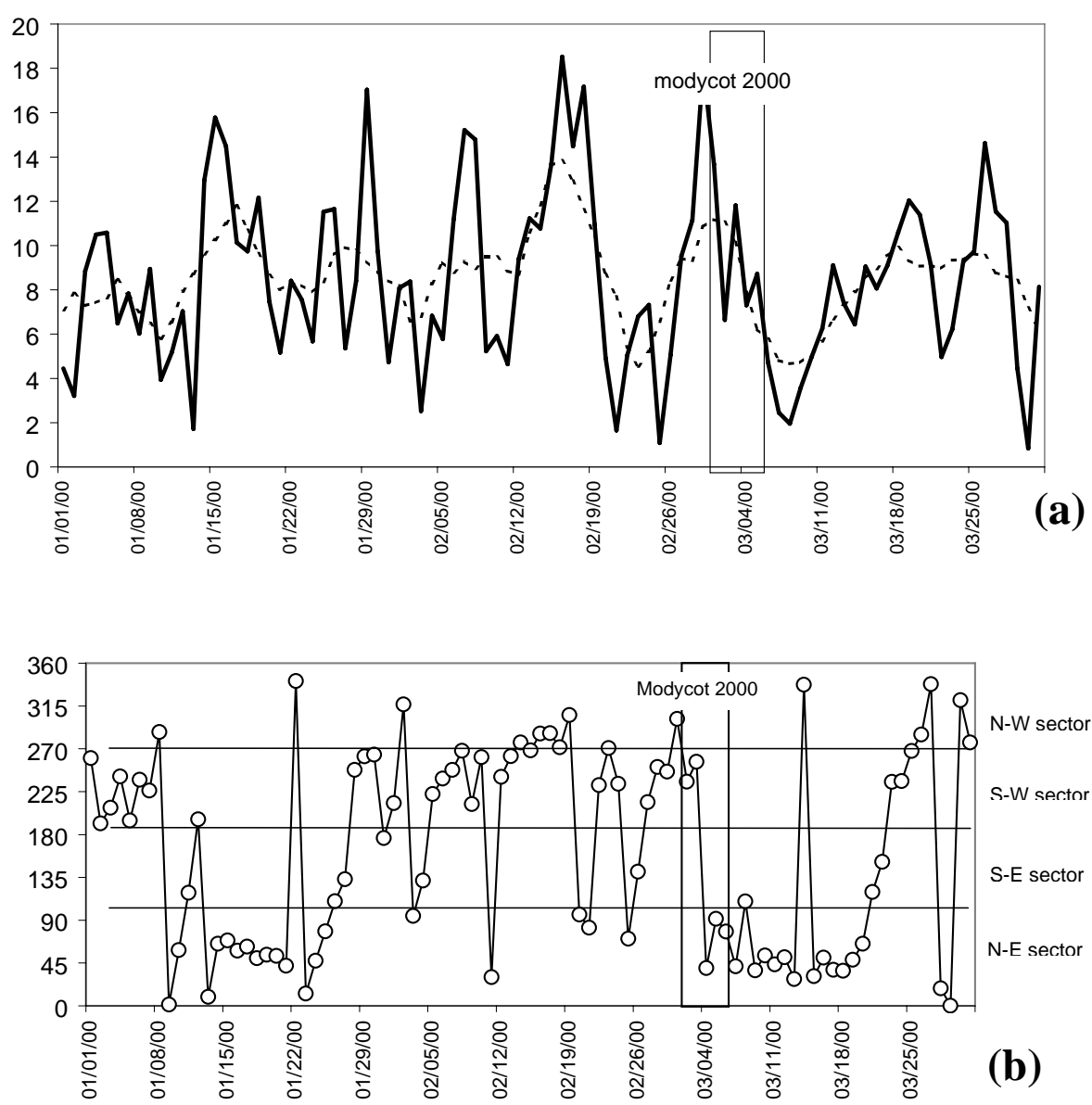

Fig. 4 : Wind speed and direction from January to March 2000

(a) Wind peed in knots; continuous line : daily average ; dotted line : 7 day moving average

(b) Wind Direction 

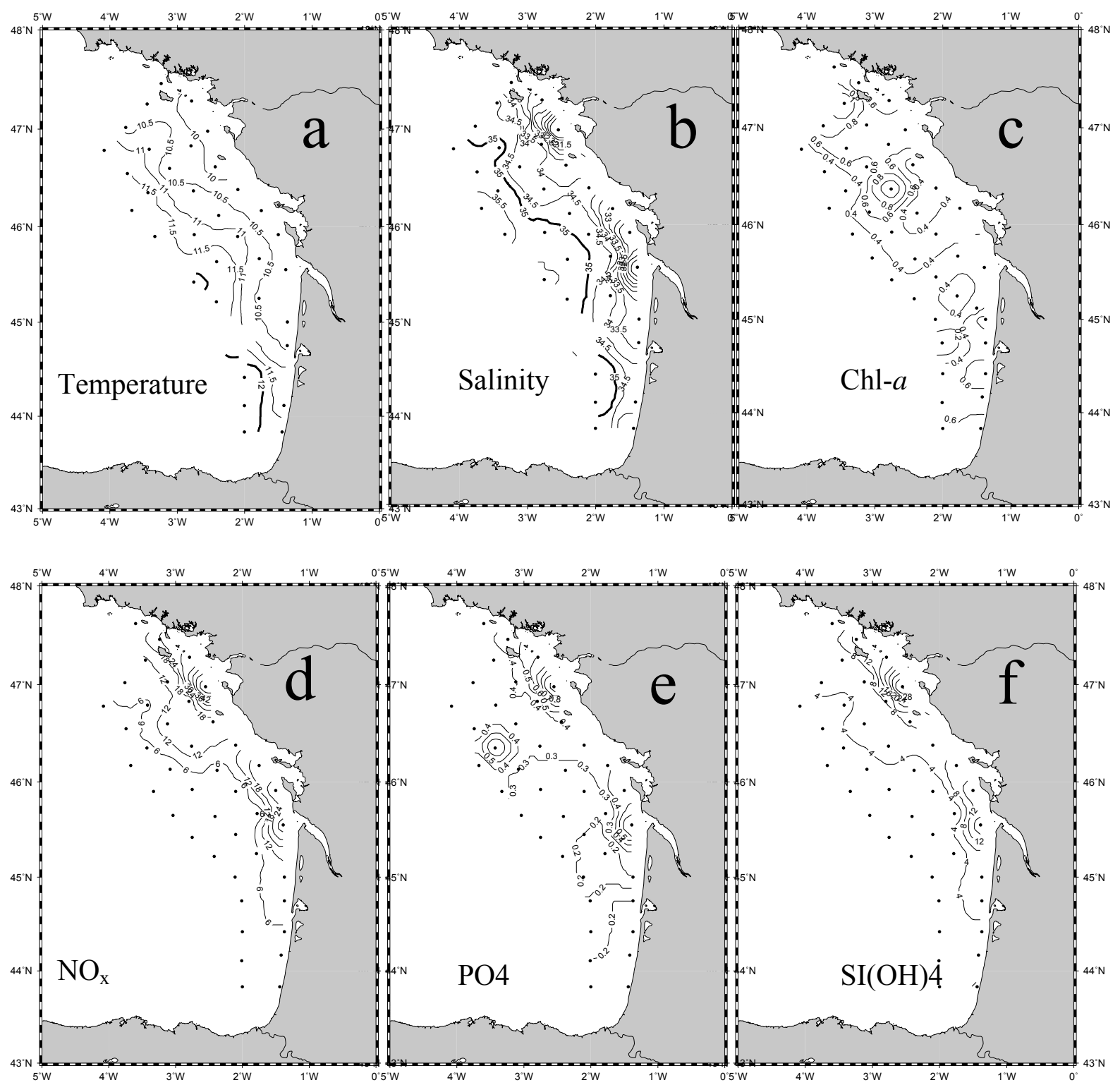

Fig. 5 : Horizontal distribution of sea surface temperature, salinity, and chlorophyll during MODYCOT 2000. (a) Temperature $\left({ }^{\circ} \mathrm{C}\right)$; (b) Salinity; (c) Chlorophyll $\left.\left(\mathrm{mg} \cdot \mathrm{m}^{-3}\right) ; \mathrm{d}\right)$ Nitric Nitrogen $(\mu \mathrm{M})$; e) Phosphate $(\mu \mathrm{M})$; and f) Silicate $(\mu \mathrm{M})$ 

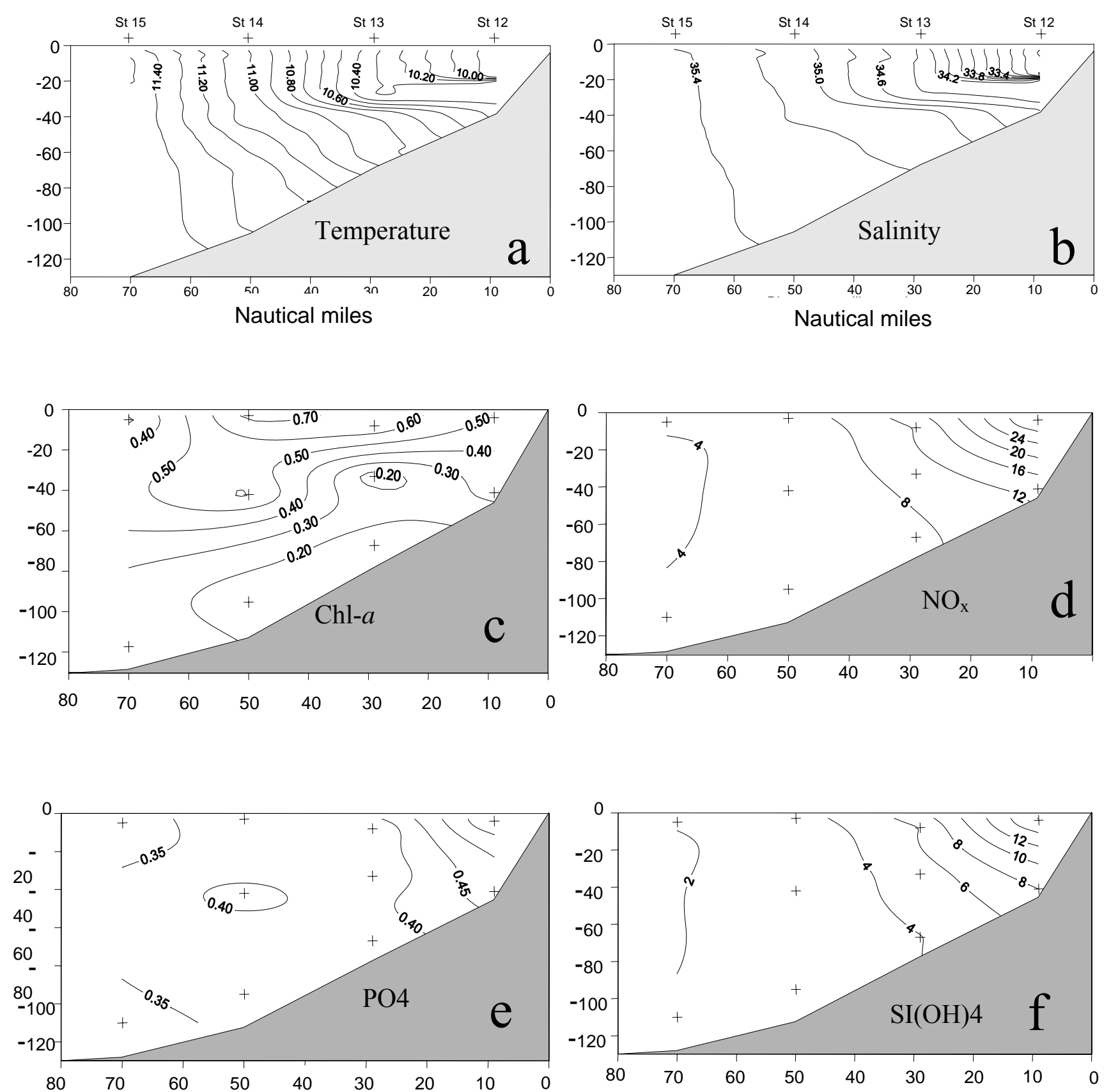

Fig.6 : Vertical profiles of temperature, salinity, nutrients and chlorophyll contoured by kriging from the data obtained at stations 12 to 15 along transect $\mathrm{T} 4$. a) temperature $\left({ }^{\circ} \mathrm{C}\right)$; b) Salinity; c) Chlorophyll-a $\left(\mathrm{mg} \mathrm{m}^{-3}\right)$, d) Nitric Nitrogen $(\mu \mathrm{M})$; e) Phosphate $(\mu \mathrm{M})$; and f) Silicate $(\mu \mathrm{M})$ 

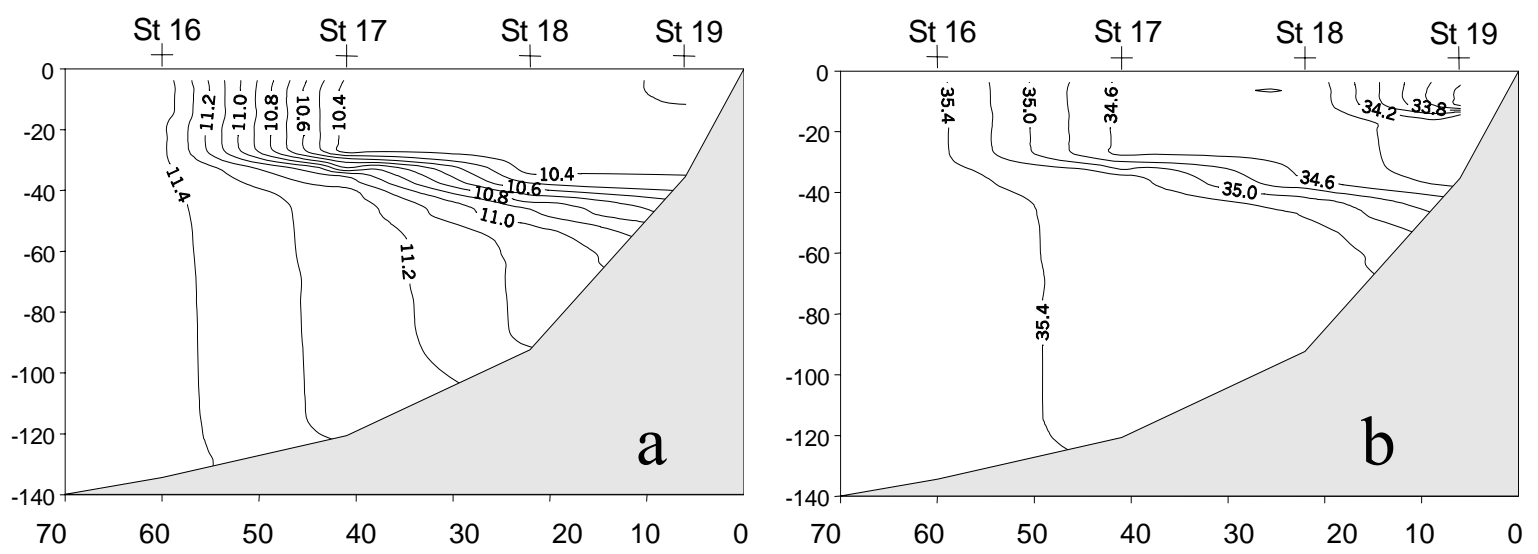

Fig. 7 : Vertical profiles of temperature (a), in ${ }^{\circ} \mathrm{C}$, and salinity (b) along transect $\mathrm{T} 5$
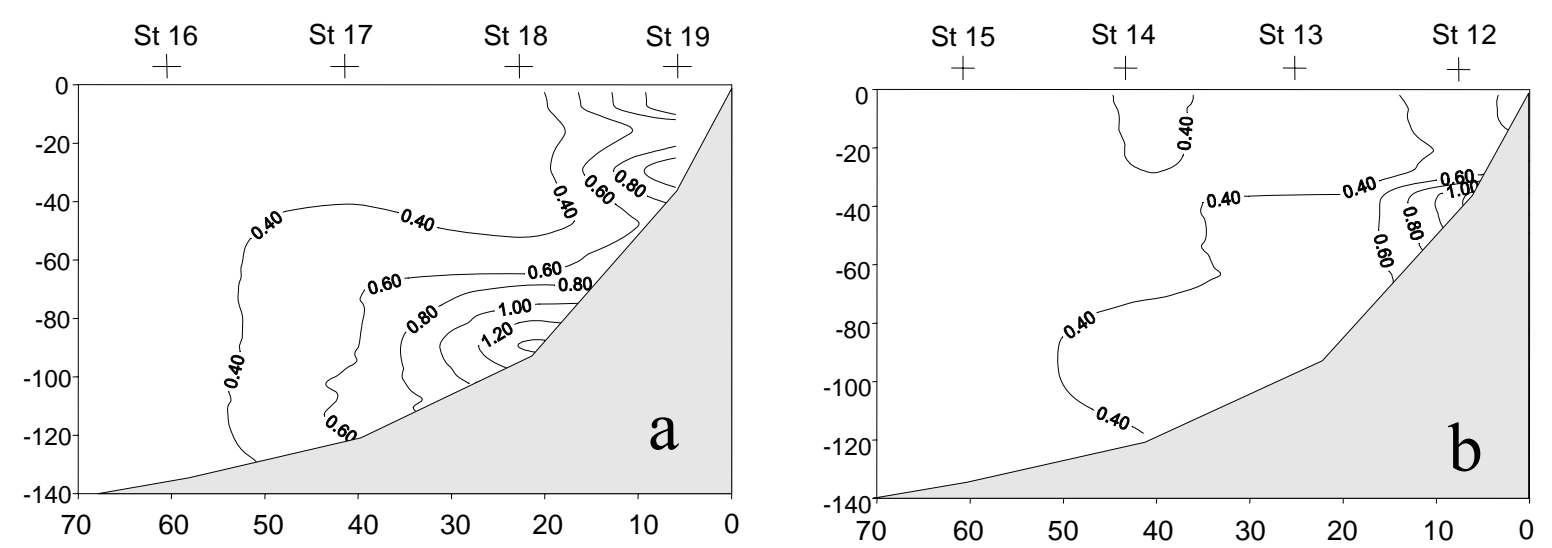

Fig. 8 : light attenuation coefficient $\mathrm{K}$ at $660 \mathrm{~nm}$ deduced from transmissiometry data;

(a) Transect T5 ; (b) Transect T4 


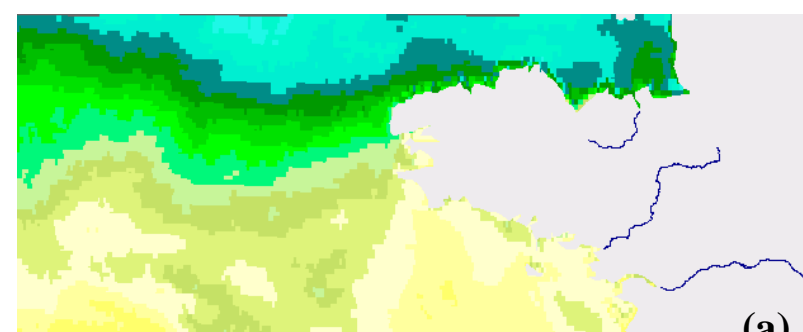

(a)

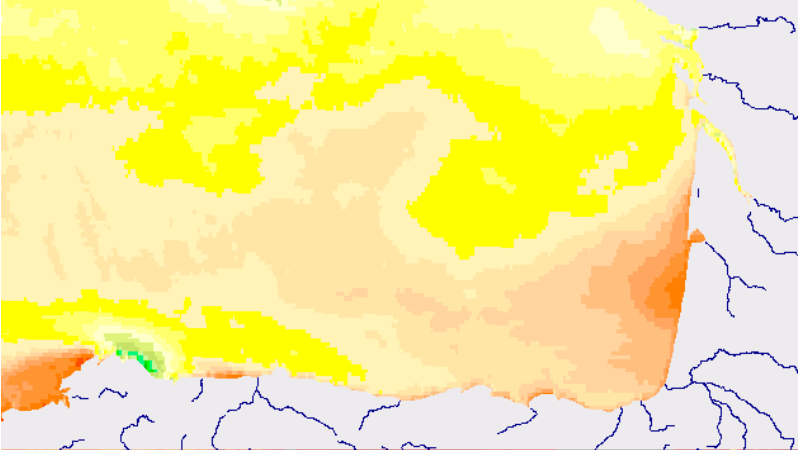

751 100l 125l 150l 175l 200ls

Solar irradiance in Watt $\mathrm{m}^{-2}$

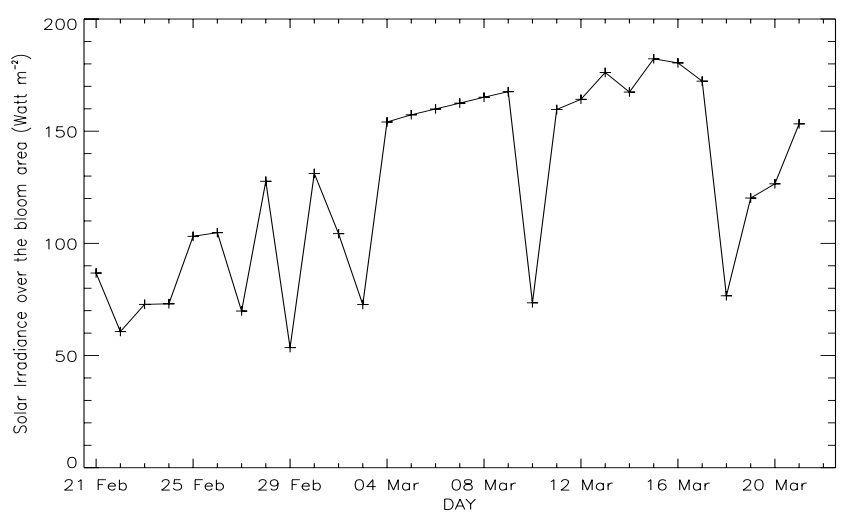

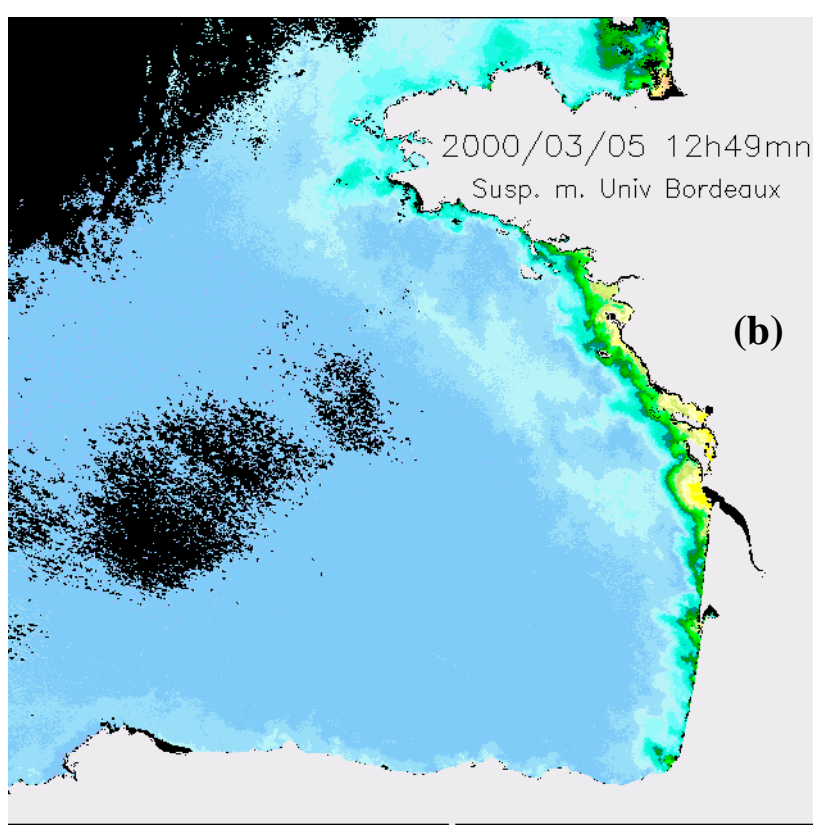

$\begin{array}{llllllllll}0.2 & 1.1 & 2.1 & 5.1 & 10.1 & 25.1\end{array}$ Suspended matter in $\mathrm{g} \mathrm{m}^{-3}$

Fig. 9 : The light distribution.

(a) Mean solar irradiance at sea surface derived from METEOSAT imagery during the 5-12 March period . (b) The suspended matter concentration derived from SeaWiFS on March 5. (c) Daily solar irradiance observed in the bloom area. 


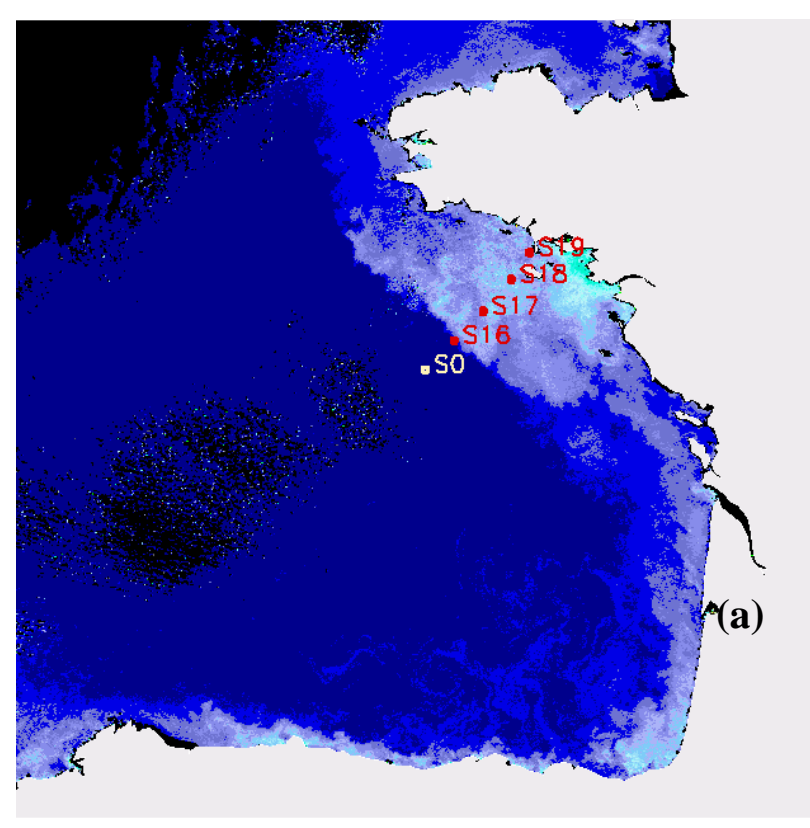

Chlorophyll concentration on March 5

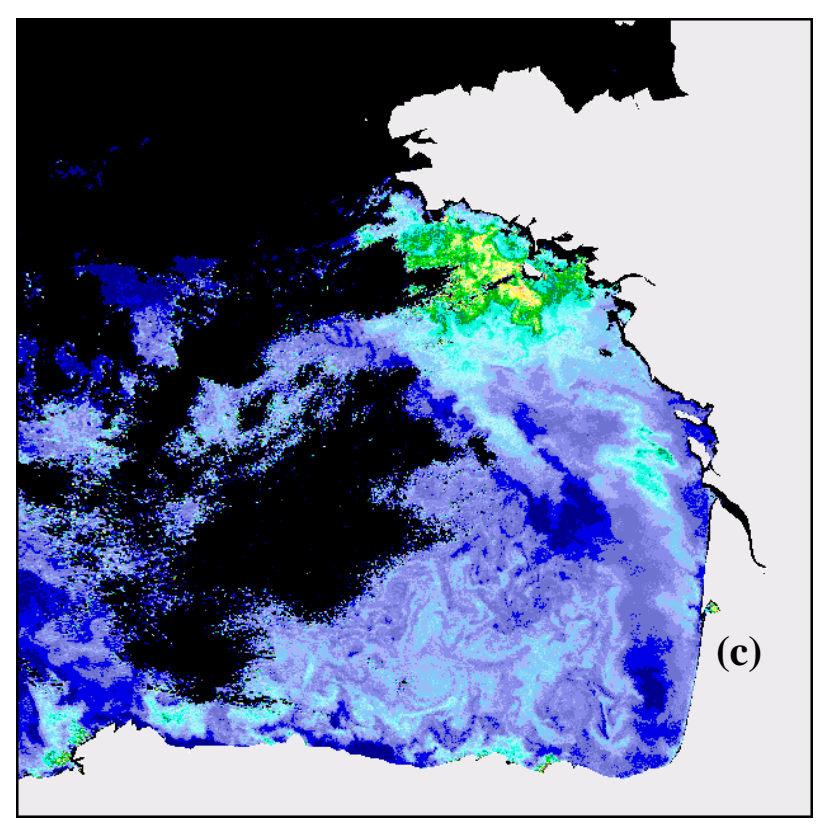

Chlorophyll concentration on March 16

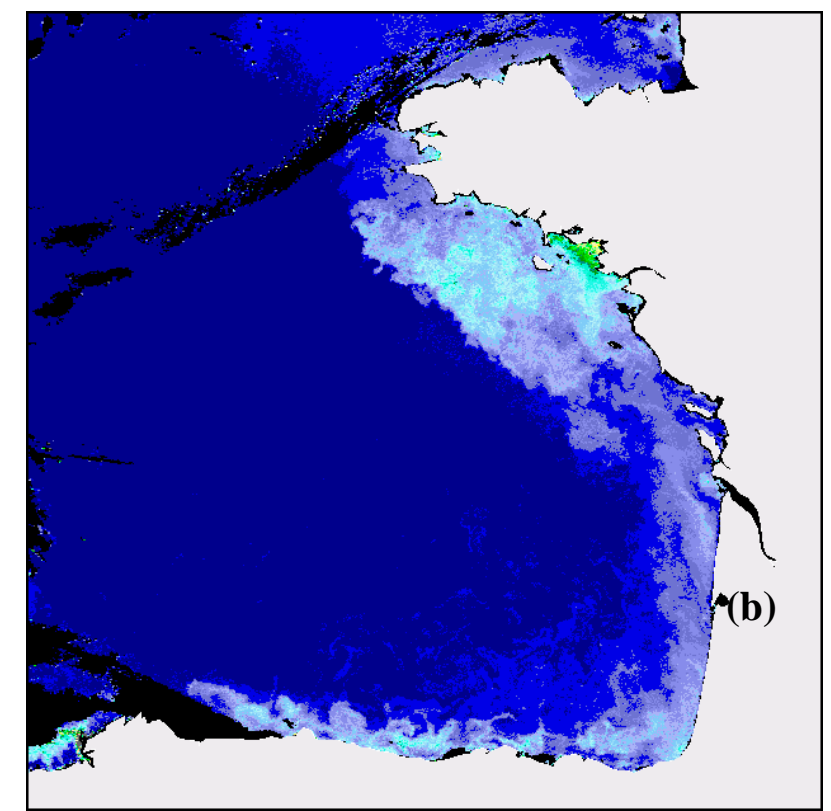

Chlorophyll concentration on March 7

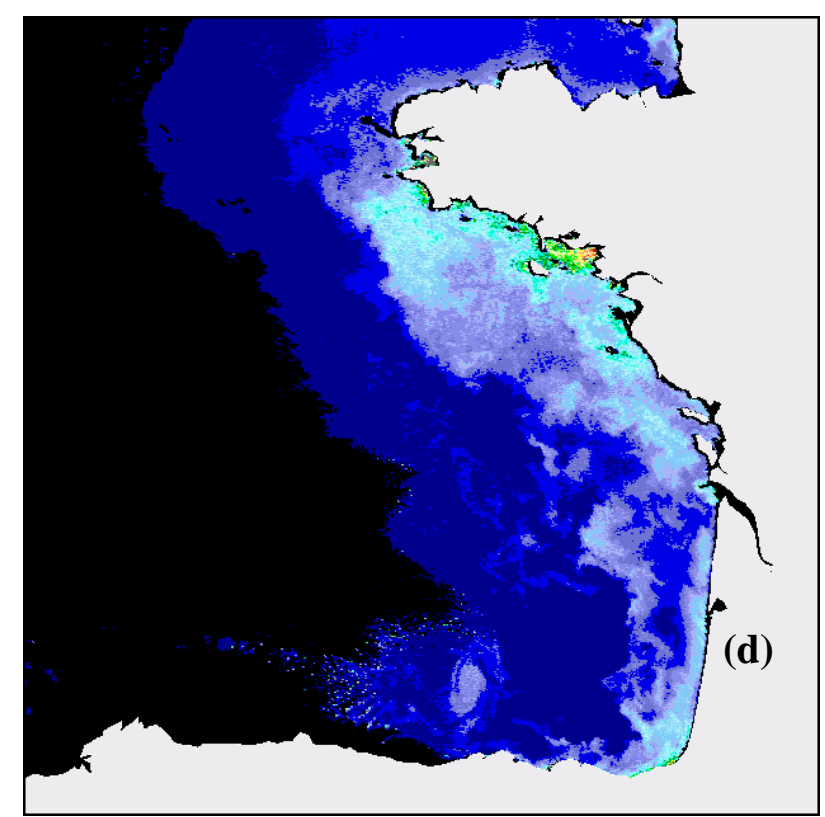

Chlorophyll concentration on April 7
Fig. 10 :Images of the Chlorophyll concentration in the initial phase of the bloom, (a) and (b), in its maximal extent (c), and after decay (d).

The MODYCOT transect T5, S16 to S19, has been drawn on (a) S0 has been added to the observed stations S16 to S19.

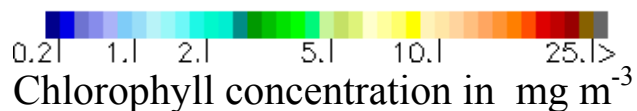



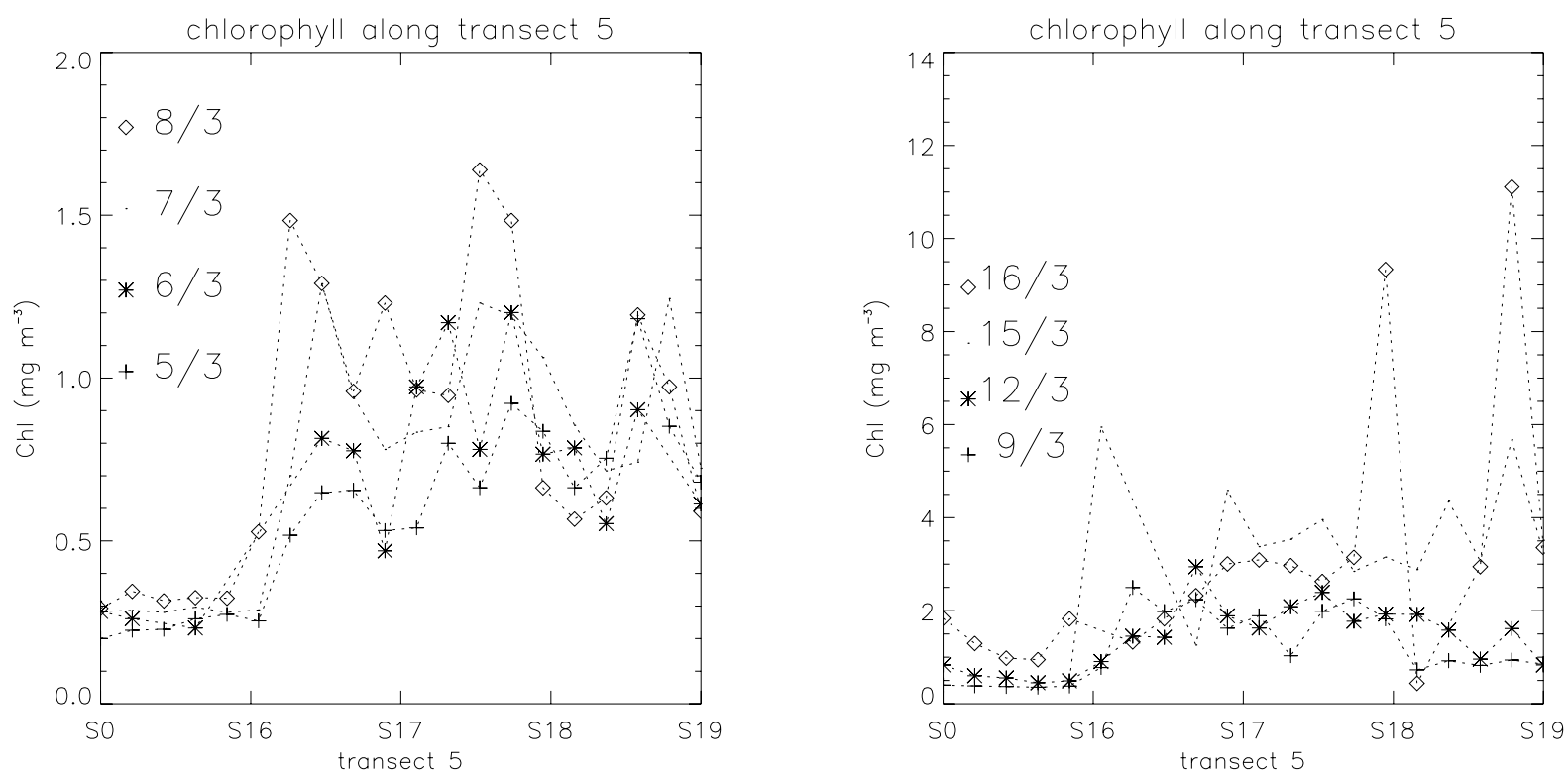

Fig. 11 : The estimated chlorophyll concentrations during the late winter bloom on locations S0, and S16, S17, S18, S19 along transect T5. (a) from March 5 to 8 (initial phase), (b) from March 9 to 16 (development phase).

S16 appears to be at the offshore boundary of the bloom area. The surface concentration of the chlorophyll shows a maximum moving inshore with time, from March 7 to 16 . Due to bad weather conditions, no image is available between March 16 and April 7. 


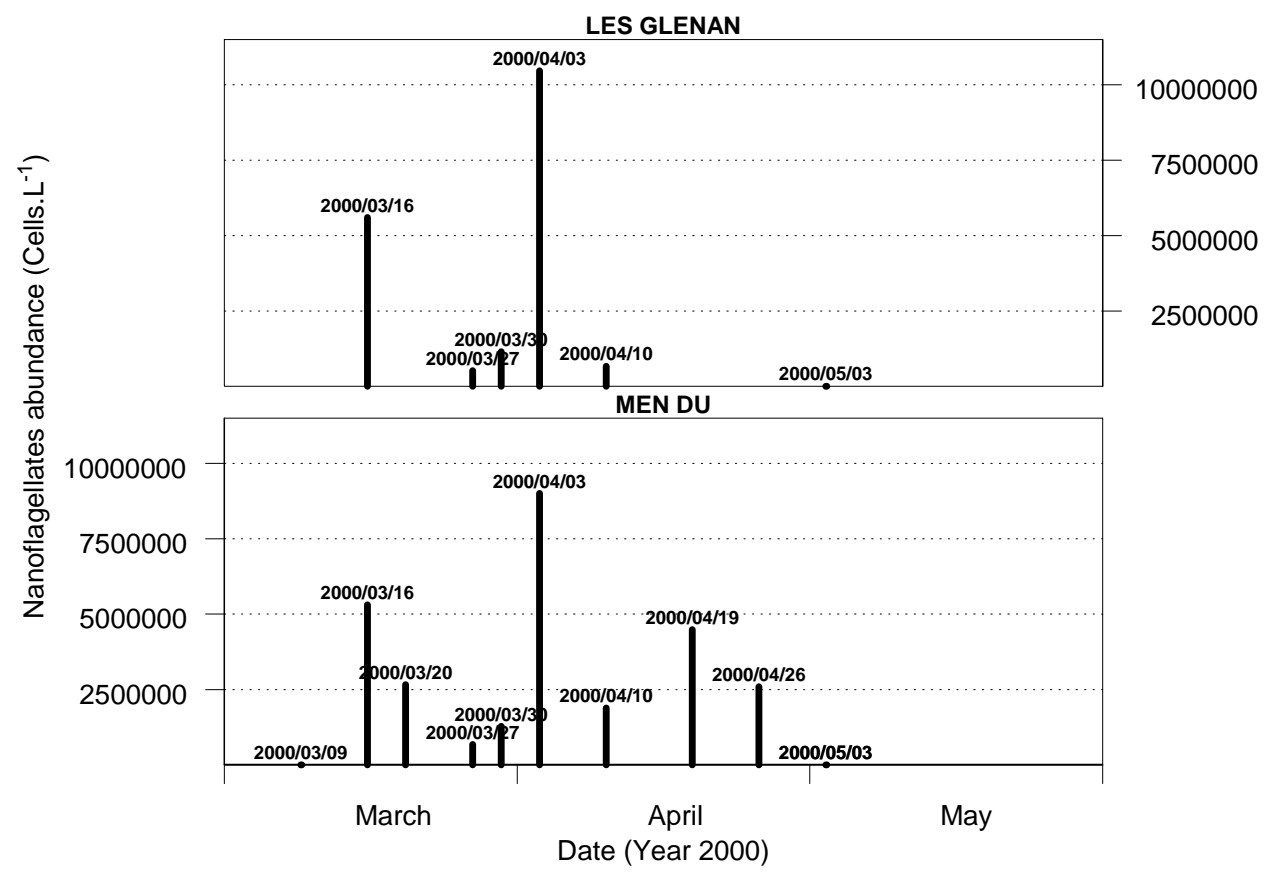

Fig. 12 : The phytoplankton observations at REPHY stations "Men Du" and "Les Glénan" 


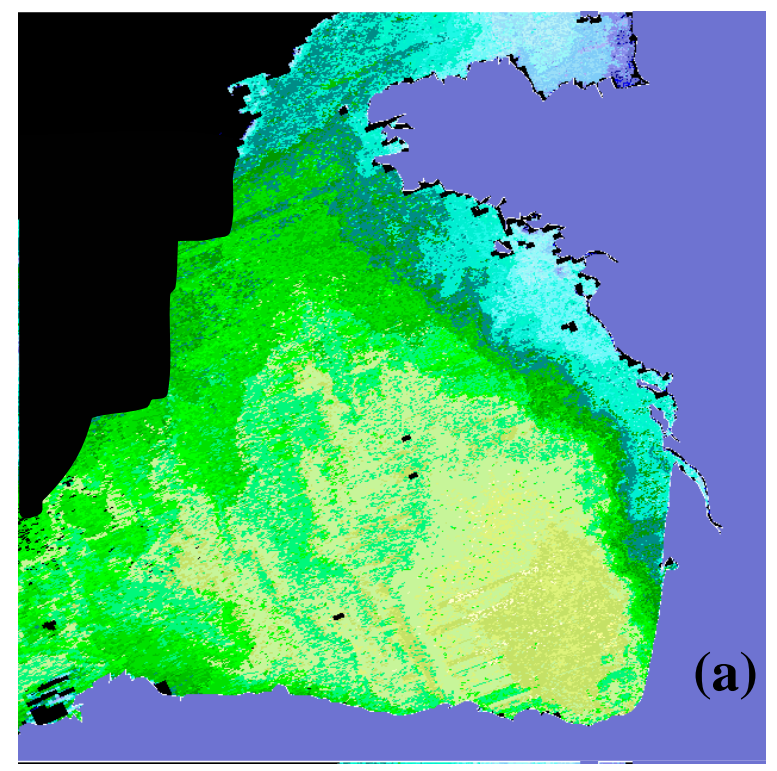

Fig. 13 : Sea surface temperature and chlorophyll concentration during the bloom.

(a) : The two-channel temperature at the beginning of the bloom for the whole Bay of Biscay,

(b), (c), and (d) : The AVHRR brightness temperature at channel $4+2{ }^{\circ} \mathrm{C}$ and the chlorophyll concentration zoomed over the bloom area during its development.

The offshore and inshore selected pixels are indicated respectively by red and white crosses on (b). The REPHY stations "Les Glenan" and "Men Du" are located on (c).

8.| $9 .|10| .11 .|12| .13 .|14| 15 ..|16|>$.

Sea Surface Temperature in ${ }^{\circ} \mathrm{C}$

Two-channel SST on March 5 at 18h19

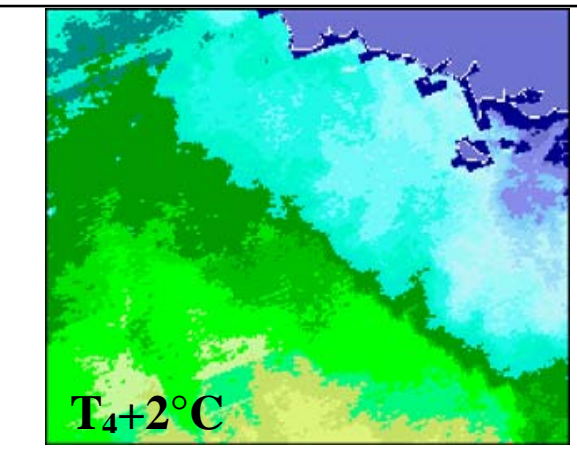

(b)

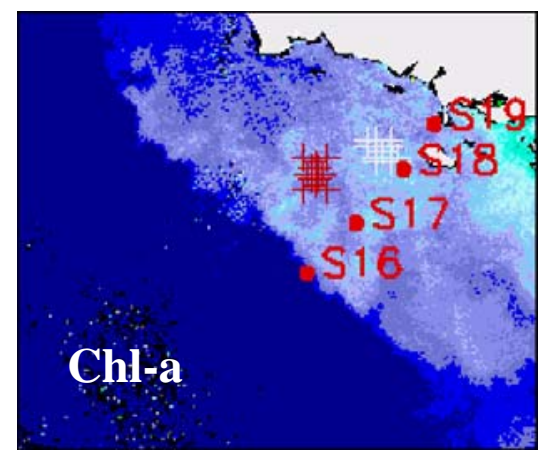

March 5

$\mathbf{T}_{4}+2^{\circ} \mathbf{C}: 18 \mathrm{~h} 19$, NOAA15

Chl-a : $12 \mathrm{~h} 50$, SeaWiFS

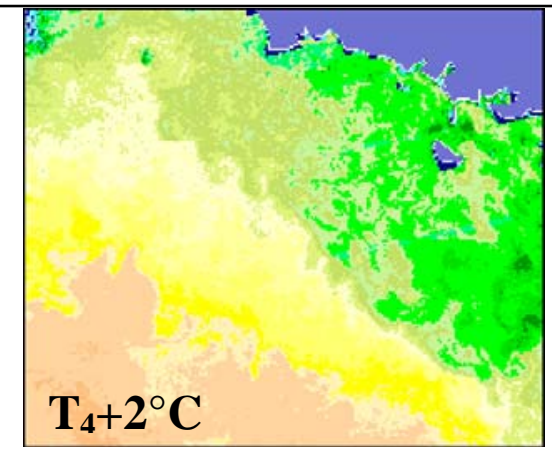

(c)

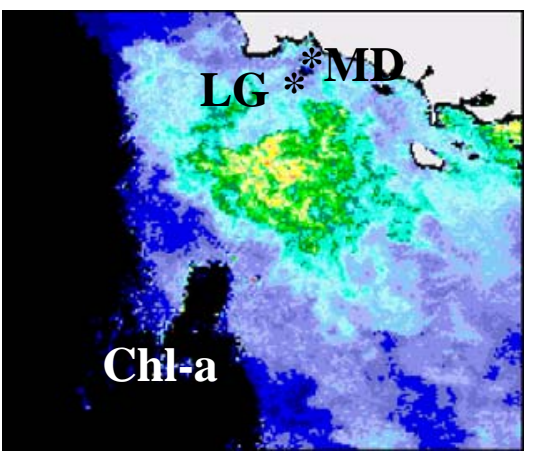

March 12

$\mathbf{T}_{4}+2^{\circ} \mathbf{C}: 19 \mathrm{~h} 01$, NOAA15

Chl-a : $13 \mathrm{~h}$, SeaWiFS

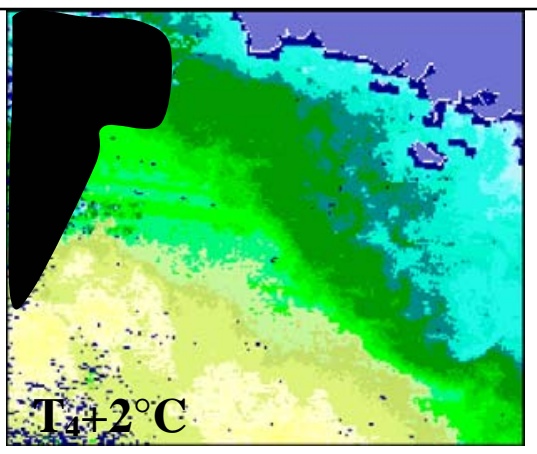

(d)

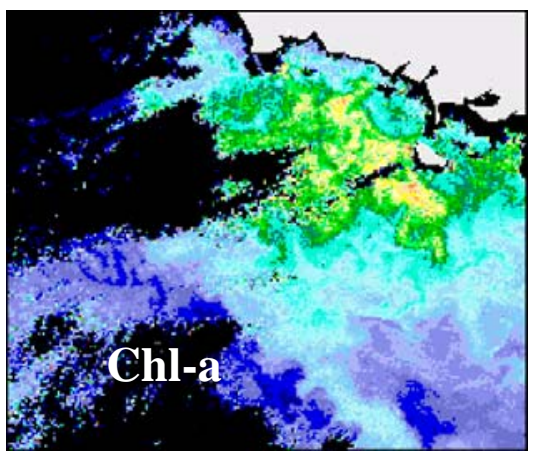

\section{March 16}

$\mathbf{T}_{4}+2^{\circ} \mathbf{C}: 4 \mathrm{~h} 15$, NOAA 14

Chl-a : $\quad 12 \mathrm{~h} 38$, SeaWiFS $\begin{array}{lllllll}10.0 & 11.0 \mathrm{l} & 12.0 \mathrm{l} & 13.0 \mathrm{l} & 14.0 \mathrm{l}\end{array}$

Temperature for the zoomed images in ${ }^{\circ} \mathrm{C}$ $\begin{array}{llllll}0.2 & 1.1 & 2.1 & 5.1 & 10.1 & 25.1>\end{array}$

Chlorophyll concentration in $\mathrm{mg} \mathrm{m}^{-3}$ 


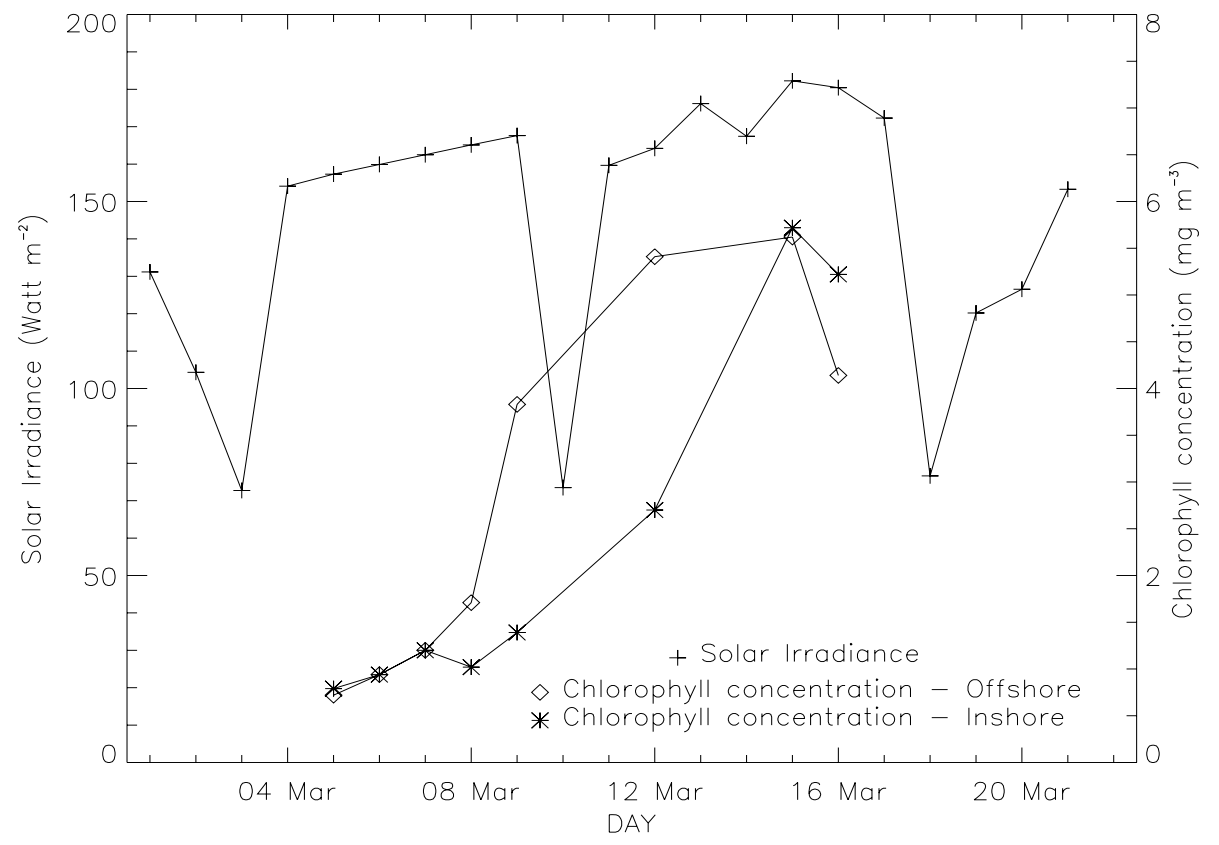

Fig. 14 : The mean daily solar surface irradiance, $\mathrm{E}_{\mathrm{SOL}}(0)$ derived from METEOSAT in the bloom area and the chlorophyll concentrations observed for both selected sets, located offshore and inshore (see locations of these data sets on Fig. 13b). 


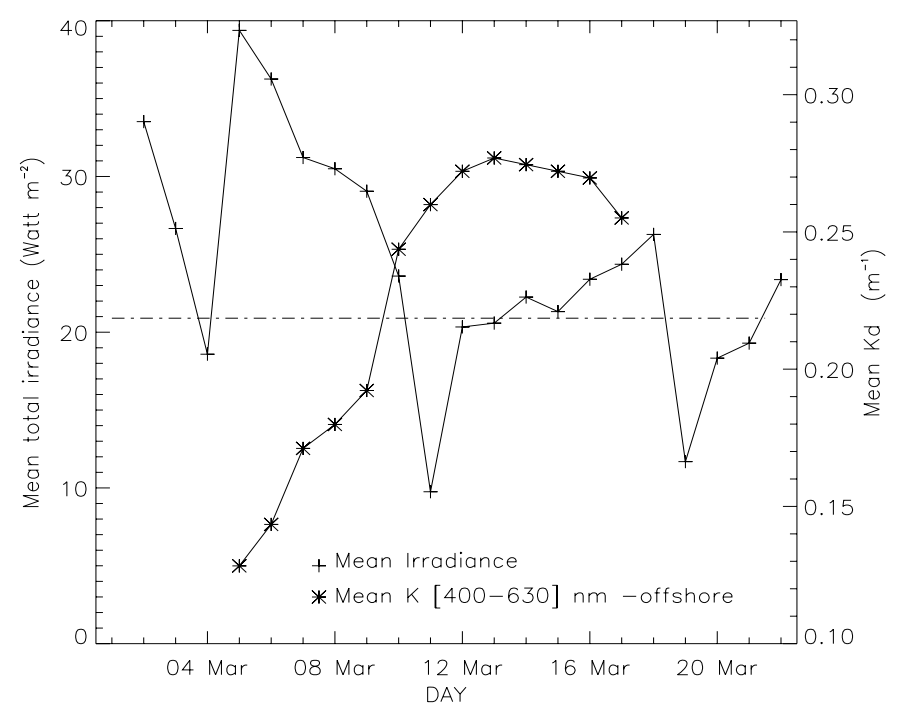

Fig. 15. Mean daily irradiance in the $30 \mathrm{~m}$ surface layer, $\overline{\mathrm{E}}_{\text {sol }}$, (in Riley's sense) derived from METEOSAT surface data and the attenuation coefficient calculated from observed or interpolated chlorophyll concentration on the offshore part of the bloom. Riley's critical value $\left(20.9 \mathrm{~W} \mathrm{~m}^{-2}\right)$ is indicated on the graph.
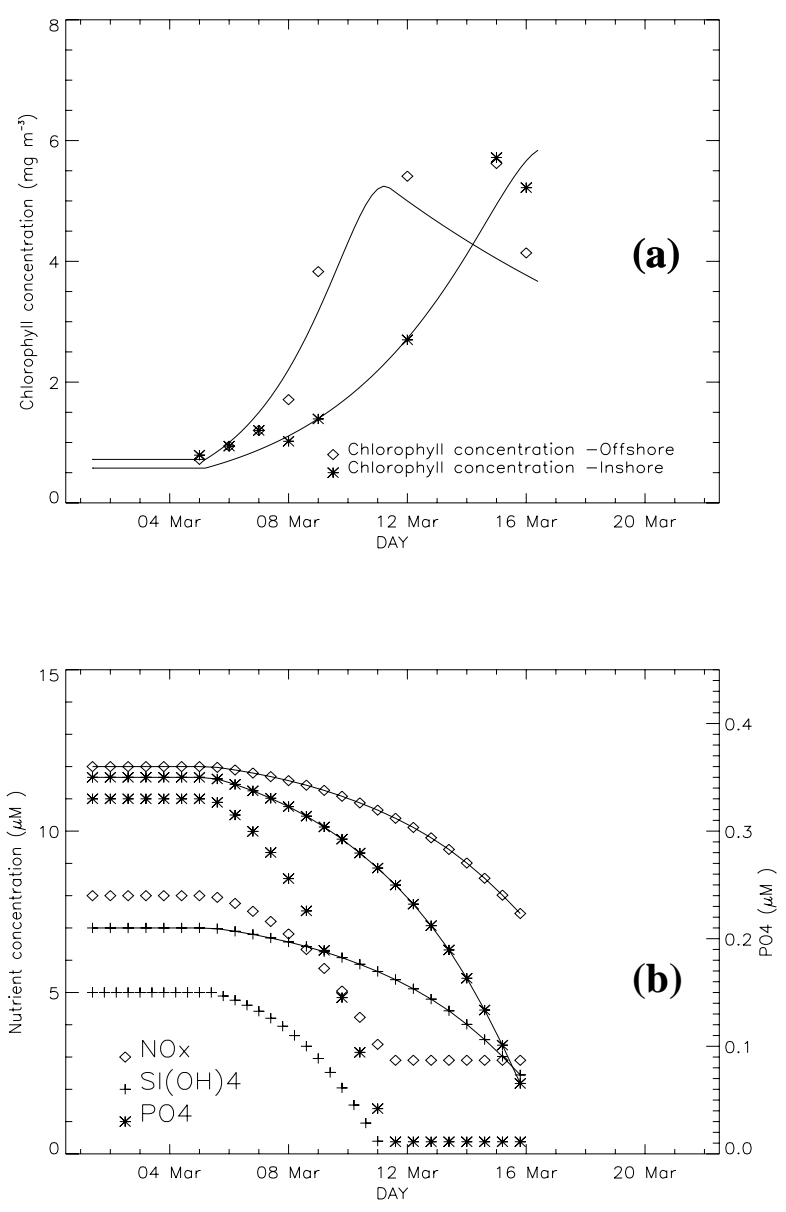

Fig. 16. Modelled growth and consumption curves on the offshore and inshore areas from March 4 to 16. (a) Observed (symbols) and modelled (continuous line) concentrations of the chlorophyll. (b) Consumption curves of nutrients $\left(\mathrm{N} 0 x, \mathrm{Si}(\mathrm{OH})_{4}\right.$, and $\left.\mathrm{PO}_{4}\right)$. For each nutrient, the upper curve, marked by connected symbols, corresponds to the inshore area. Offshore, $\mathrm{PO}_{4}$ is the limiting nutrient and $\mathrm{Si}(\mathrm{OH})_{4}$ is almost exhausted. Total consumption of $\mathrm{PO}_{4}$ occurs on March 12. Inshore, the bloom is still ongoing on March 16 but a complete consumption of $\mathrm{PO}_{4}$ is expected for March 17. 


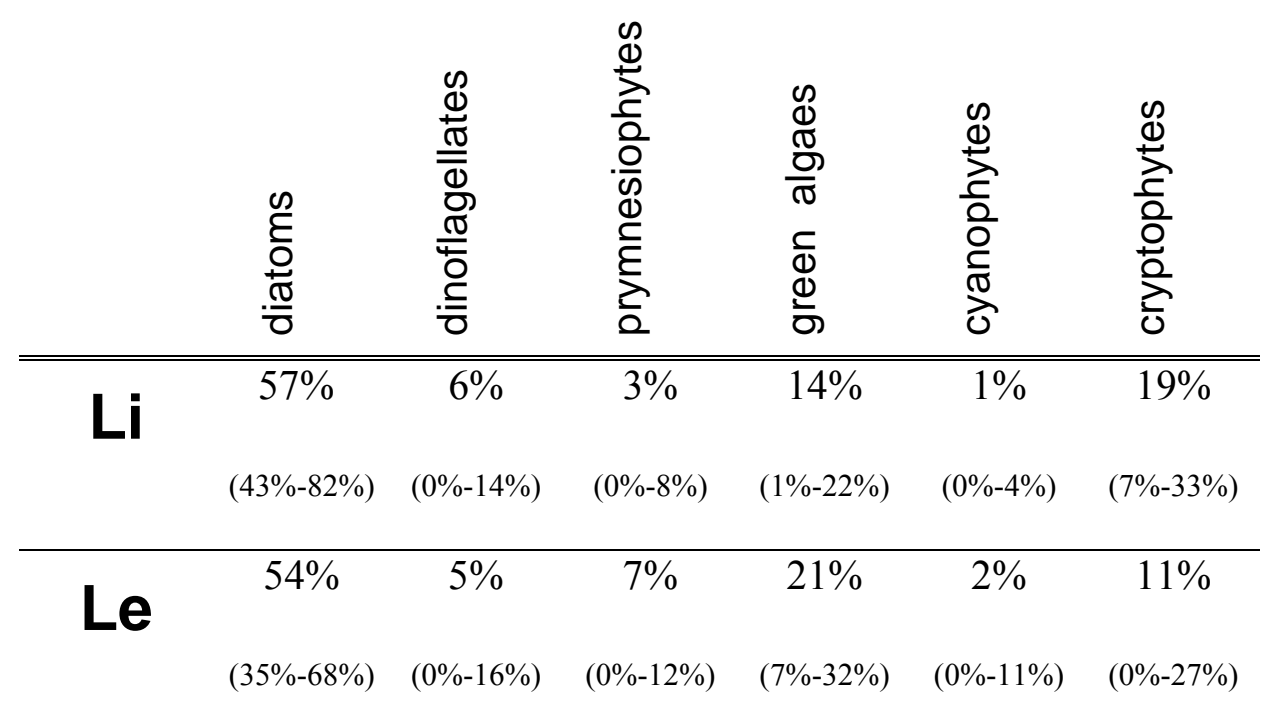

Table1 : Distribution (mean and extreme percentages measured) of the mean algal classes obtained by CHEMTAX for the coastal and offshore parts of transect 4 and 5 (Li, inside Loire, and Le, outside Loire respectively) .

\begin{tabular}{ccccc}
\hline \hline Transect & Station & $\begin{array}{c}\mathrm{Z}_{\mathrm{m}} \\
(\mathrm{m})\end{array}$ & $\begin{array}{c}\mathrm{K}_{\mathrm{PAR}} \\
\left(\mathrm{m}^{-1}\right)\end{array}$ & $\begin{array}{c}\mathrm{E}_{\mathrm{SOL}}(0) \\
\left(\mathrm{W} \mathrm{m}^{-2}\right)\end{array}$ \\
\hline 4 & Station 14 & 30 & 0.36 & 226 \\
4 & Station 15 & 120 & 0.33 & 827 \\
\hline 5 & Station 16 & 100 & 0.15 & 313 \\
5 & Station 17 & 30 & 0.18 & $\mathbf{1 1 3}$ \\
5 & Station 18 & 30 & 0.23 & 144 \\
5 & Station 19 & 20 & 0.49 & 205 \\
\hline
\end{tabular}

Table 2 : Minimum surface solar irradiance $\mathrm{E}_{\mathrm{SOL}}(0)$ necessary to initiate a bloom following Riley's hypothesis at different MODYCOT stations located on transects T5 and T4. $\mathrm{K}_{\mathrm{PAR}}$ is the attenuation coefficient of the descending light observed in the surface layer of depth $\mathrm{Zm}$. 